\title{
Minimum Wage Effects Across the Private and Public
}

\author{
Sectors in Brazil
}

\author{
Sara Lemos ${ }^{*}$ \\ University of Leicester
}

June 24, 2004

\begin{abstract}
There is very limited evidence on the effects of the minimum wage in developing countries, and none whatsoever on the effects of the minimum wage on the public sector. Most of the evidence available uses (US) private sector data. However, evidence regarding the private sector need not carry over to the public sector. This paper estimates minimum wage effects across sectors using an under-explored monthly Brazilian household survey from 1982 to 2000 . The minimum wage was found to compress the wage distribution of both sectors. However, consistent with a stronger compression effect, more adverse long run employment effects are observed in the private sector.

Keywords: minimum wage, labor costs, employment, public sector, Brazil.

JEL code: J38.
\end{abstract}

${ }^{*}$ Dr. Sara Lemos, University of Leicester, Economics Department, University Road, Leicester LE1 7RH, England, +44 (0)116252 2480, +44 (0)1162522908 (fax), sl129@leicester.ac.uk.

${ }^{\dagger}$ Special thanks to Arthur Van Soest, Christian Dustman and Jerzy Szroeter. Also thanks to Alan Krueger, Charles Brown, Dave Wittenburg, Kenneth Couch, Madeleine Zavodny and Michael Baker. And thanks to comments of various discussants and participants in the following conferences: IZA-Germany, ESPE-Germany, SPiE-Lisbon, SOLE-America, ESPE-Spain, EEA-Italy, LAMES-Brazil, LACEA-Spain, RES-England, SBE-Brazil and LACEA-Mexico. 


\section{Minimum Wage Effects Across the Private and Public Sectors in Brazil}

There is very limited evidence on the effects of the minimum wage in developing countries, and none whatsoever on the effects of the minimum wage on the public sector. Most of the evidence available uses (US) private sector data. However, evidence regarding the private sector need not carry over to the public sector. This paper estimates minimum wage effects across sectors using an under-explored monthly Brazilian household survey from 1982 to 2000. The minimum wage was found to compress the wage distribution of both sectors. However, consistent with a stronger compression effect, more adverse long run employment effects are observed in the private sector. 


\section{Introduction}

The evidence in the international literature shows that the minimum wage compresses the wage distribution, although evidence of negative employment effects (Neumark and Wascher, 1992 and 2000; Williams, 1993; Burkhauser et al., 2000), as predicted by the standard theory, has been challenged by evidence of non-negative effects (Card and Krueger, 1995 and 2000; Dickens et al, 1999; Machin et al. 2003). The limited evidence for Latin America suggests that the compression effect is a lot stronger in developing countries than it is in developed countries, and is accompanied by stronger adverse employment effects (Castillo-Freeman and Freeman, 1992; Bell, 1997; Maloney and Mendez, 2004; Montenegro and Pages, 2004). The scanty evidence for Brazil also suggests that the minimum wage strongly compresses the wage distribution, but it suggests a small adverse employment effect (Fajnzylber, 2001; Neumark et al., 2003; Lemos, 2004).

This evidence uses either private sector or overall (private and public sector) data. There is no available evidence in the literature on the effects of the minimum wage on the public sector. However, evidence regarding the private sector need not carry over to the public sector. The wage and employment effects predicted by the standard theory rely on a profit maximising firm, not on a Government employer that can cover the higher wage bill by raising taxes, reducing expenditure, or simply printing money, as is often the case in developing countries. If the public sector has an inelastic labour demand, the associated non-negative (or less negative) employment effect might offset some of the negative employment effect observed in the private sector, diluting the overall employment effect to be less adverse than the later. This is particularly so if the public sector is overpopulated by minimum wage workers, as in Brazil, where $15 \%$ of the labour force are civil servants and $7 \%$ of those earn a minimum wage. Taking the overall employment effect as an estimate of the effect on the private sector might mislead policymakers to increase the minimum wage more generously than they would otherwise do. 
Thus, the main contribution of this paper to the literature and to policymaking is to fulfil the gap on evidence on the effect of the minimum wage across the private and public sectors. The effect of the minimum wage throughout the wage distribution is estimated for each sector, and the total employment effect in each sector is decomposed into hours and jobs effects. Another contribution of this paper is to use an under-explored monthly Brazilian household survey from 1982 to 2000 . As the non-US literature is scanty, this will extend the current understanding on the effects of the minimum wage in developing countries.

This paper is organized as follows. Section 2 discusses the data, Sections 3 and 4 estimate wages and employment effects, and Section 5 concludes. The minimum wage was found to compress the wage distribution of both sectors. In the private sector, consistent with a stronger compression effect, more adverse long run total employment effects were observed. In the public sector, no evidence of adverse employment effects was uncovered, suggesting an inelastic labour demand curve.

\section{Data}

The data is the Monthly Employment Survey, a rotating panel data similar to the US Current Population Survey, together with the Consumer Price Index. This data is available for six Brazilian metropolitan regions between 1982 and 2000, and it was aggregated across regions and across months; each cell had 13.000 observations on average.

Figure 1.a shows the log real minimum wage over time. The negative trend over time is due to persistent under-indexation of the nominal minimum wage according to the rules of successive stabilization plans. ${ }^{1}$ The saw-toothed pattern over time is due to the quick erosion of large and frequent nominal minimum wage increases by the subsequent inflation.

\footnotetext{
${ }^{1}$ The minimum wage does not vary across regions, gender or age. Its coverage is full, but accommodation and food costs can be deducted from the wage. That might account for some below minimum wage workers, although the majority of those are informal sector workers. Notice the proportion of below minimum wage workers working in the public sector in Figure 2.b (between $12 \%$ and $21 \%$ in a poor region, and between $9 \%$ and $13 \%$ in the aggregate), where presumably there is full compliance with the minimum wage legislation.
} 
Figure 1 shows the $25^{\text {th }}, 50^{\text {th }}$ and $75^{t h}$ percentiles of the log real earnings distribution both for the private and public sectors over time. The trend is negative for all percentiles. The correlations with the log real minimum wage (on the top of each figure) suggest that these correlations are stronger for the private sector. The correlation with the $25^{\text {th }}\left(75^{\text {th }}\right)$ percentile is $0.86(0.75)$ in the private sector, and $0.66(0.46)$ in the public sector.

Figure 2 shows the Kernel log real earnings distribution for each month of 1992 for both sectors before and after each minimum wage increase. The two main features in these distributions are the spike at the minimum wage and the compression effect observed in both sectors. First, the spike is larger in the private sector. On average over the sample period, the spike (i.e. the fraction of workers earning \pm 1.02 times the minimum wage) is $11 \%(7 \%)$ in the private (public) sector. Nonetheless, the spike shows great variation over the sample period, for example, it jumped from $2.5 \%$ to $14.5 \%$ (1.5\% to $9 \%$ ) in the private (public) sector in response to the September of 1991 increase. This is large when compared to the $4 \%$ spike in the US in 1993 (Dolado et al., 1996). Second, in line with a more binding minimum wage and a larger spike in the private sector, the compression effect is stronger in that sector. Figures titled April-May, August-September and December-January show the compression effect (see the right-most distribution) after the increase.

Figure 3 shows three employment variables for both the private and public sectors over time: $\log$ total average hours worked in the working population, log average hours worked for those working and log employment rate. All three variables show a slightly negative (positive) and significant (not significant) trend for the private (public) sector over time. ${ }^{2}$ The correlations with the log real minimum wage (on the top of each figure) suggest that these correlations are once again stronger for the private sector. The correlations between each of the three variables and the log real minimum wage are $0.41,0.38$ and $0.19(-0.09$, -0.12 and -0.01 ) in the private (public) sector.

\footnotetext{
${ }^{2}$ As a result of the 1988 Constitutional shortening of the length of the working week and working day, all three variables show clear changes in their trend after that in the private but not in the public sector.
} 


\section{$3 \quad$ Wage Effects}

The wage effects are estimated using a standard model in the literature (Brown, 1999):

$$
\Delta \ln W_{r t}=\alpha^{w}+\beta^{w} \Delta \ln M W_{t}+\gamma^{w} \pi_{r t-1}+\delta^{w} \Delta u_{r t-1}+\lambda^{w} \Delta X_{r t}+f_{r}^{w}+f_{t}^{w}+\epsilon_{r t}^{w}
$$

where $W_{r t}$ is real hourly average wages; $M W_{t}$ is real hourly minimum wage ${ }^{3} \pi_{r t-1}$ is past inflation; $u_{r t-1}$ is past unemployment rate; $X_{r t}$ are labour supply shifters; $f_{r}^{w}$ and $f_{t}^{w}$ are region and time fixed effects; and $\epsilon_{r t}^{w}$ is the error term in region $r$ and month $t, r=1, \ldots, 6$, and $t=1, \ldots, 214$. Region and time fixed effects are modelled by region and month dummies. Regional dummies model region specific trends because regions are expected to differ not only in their business cycles but also in the pace of the cycle. Supply shifters are the population proportion: of youngsters, children younger than 10 years old, women, illiterate, retiree and student; in urban areas, working in the informal sector, in the public sector, in the building construction and in the metallurgic industry; working on two jobs; with basic and high school education and the average number of years of education.

This model can be estimated not only using average wages, but also the $5^{\text {th }}, 10^{\text {th }}, 15^{\text {th }}$, $20^{t h}, 25^{t h}, 30^{t h}, 35^{t h}, 40^{t h}, 45^{t h}, 50^{t h}, 90^{t h}$ and $95^{t h}$ wage distribution percentiles. This makes it possible to estimate the effect of the minimum wage throughout the distribution (Dickens et al., 1999). The models were sample size weighted, White-corrected for heteroskedasticity and corrected for serial correlation across and within regions (assuming an autoregressive process specific to each region).

The real minimum wage, together with the "Kaitz index" (defined as the ratio of the

\footnotetext{
${ }^{3}$ The hourly minimum wage is the monthly minimum wage divided by $44 \mathrm{x} 4.3$ after, and $48 \mathrm{x} 4.3$ until September of 1988, because the new Constitution shortened the working week. Similarly, the hourly wage rate is monthly earnings divided by the weekly hours worked multiplied by 4.3. All regression estimates in the paper were robust to hourly and monthly definitions.
} 
minimum wage to average wage adjusted for coverage of the legislation), are the typical minimum wage variables used in the literature. Although both variables vary across regions and over time, when the minimum wage is constant across regions, the variation in the ratio is driven by the variation in the denominator. As a result, the effect of the inverse of the deflator (or average wages) on wages is what is ultimately estimated (Welch and Cunningham, 1978). Although a constant minimum wage presents a difficulty in estimation, Card (1992) exploited this to suggest a new minimum wage variable, "fraction affected", defined as the proportion of workers earning a nominal wage between the old and the new nominal minimum wage. The intuition is that a constant minimum wage affects a different proportion of workers depending on the initial level and the shape of the wage distribution across regions.

Brown (1999) compares "fraction affected" and the "Kaitz index" and concludes that the former is conceptually cleaner because it measures the effect of the minimum wage at the point that really matters. Nonetheless, "fraction affected" is constant at zero when the nominal minimum wage is constant and does not capture its erosion in relation to other wages. In order to capture this erosion, "fraction affected" is here defined as the proportion of workers earning a real hourly wage between (-1.02 times) the old and (+1.02 times) the new real hourly minimum wage. Thus, to ensure identification, the difference of log hourly minimum wage in Equation (1) is replaced by "fraction affected". The "fraction affected" estimates are then multiplied by 4.5 , which is the approximate elasticity of the "fraction affected" with respect to the real minimum wage. ${ }^{4}$ Card and Krueger (1995) interpret their "fraction affected" estimates in a similar way.

Table 1 shows positive and mostly significant $\beta^{w}$ estimates for the private and for the public sectors. A $10 \%$ increase in the real minimum wage increases the wages of those

\footnotetext{
${ }^{4}$ The 4.5 estimate is the coefficient of the real minimum wage on a regression of "fraction affected" on the difference of $\log$ real minimum wage and the other regressors in Equation (1). This estimate was robust to using the regressors in Equations (2) and (2') instead, and it was always statistically significant at the usual levels of significance.
} 
in the $10^{t h}\left(20^{t h}\right)$ percentile by $1.50 \%(5.26 \%)$ in the private and by $5.71 \%(3.94 \%)$ in the public sector. Table 1 also shows estimates for percentile ratios and standard deviation regressions, whereby percentile ratios and the standard deviation of the log real hourly wage distribution replace the log real hourly average wages in Equation (1). A $10 \%$ increase in the real minimum wage decreases the $90^{t h}-10^{t h}$ percentile gap by $1.17 \%(4.52 \%)$, decomposed into a decrease in the $90^{t h}-50^{t h}$ gap of $2.22 \%(0.82 \%)$ and in the $50^{t h}-10^{t h}$ gap of $1.09 \%$ $(3.63 \%)$ in the private (public) sector. This suggests that the minimum wage compresses the wage distribution of both sectors, but that the compression effect extends higher in the private sector. This is in line with the evidence discussed in Section 2 that shows that the minimum wage is more binding and that the spike is larger in the private sector wage distribution (see Figure 2). This is also in line with previous empirical evidence on the (overall) wage effect across the distribution in the international and Brazilian literature (see Section 1).

\section{Employment Effects}

The employment effects are estimated using a standard model in the literature (Brown, 1999):

$$
\Delta \ln N_{r t}=\alpha^{n}+\beta^{n} \Delta \ln M W_{t}+\gamma^{n} \pi_{r t-1}+\lambda^{n} \Delta X_{r t}+f_{r}^{n}+f_{t}^{n}+\epsilon_{r t}^{n}
$$

where $N_{r t}$ means, in turn, average hours in the population $\left(T_{r t}\right)$, average hours for those working $\left(H_{r t}\right)$ and the employment rate $\left(E_{r t}\right) ; f_{r}^{n}$ and $f_{t}^{n}$ are region and time fixed effects modelled as before, and $\epsilon_{r t}^{n}$ is the error term. As the employment response to minimum wage increases might be lagged, dynamics are allowed: 
$\Delta \ln N_{r t}=\alpha^{n}+\beta^{n} \Delta \ln M W_{t}+\gamma^{n} \pi_{r t-1}+\lambda^{n} \Delta X_{r t}+\sum_{l=1}^{24} \rho_{l}^{n} \Delta \ln N_{r t-l}+f_{r}^{n}+f_{t}^{n}+\epsilon_{r t}^{n}$

Estimating Equations (2) and (2') separately using each of the three employment variables ( $T, H$ and $E$ ), the estimate of the real minimum wage in the $T$ equation equals the sum of the estimates of the real minimum wage in the $H$ and $E$ equations, i.e. $\beta_{T}^{n}=\beta_{H}^{n}+\beta_{E}^{n}{ }^{5}$ This makes it possible to decompose the total effect of a minimum wage increase on employment into hours and jobs effects. As in Section 3, to ensure identification, the difference of $\log$ hourly minimum wage in Equations (2) and (2') is replaced by "fraction affected", whose estimates are multiplied by 4.5 . Also, the models were again sample size weighted, White-corrected, and corrected for serial correlation.

Table 2 shows $\beta_{T}^{n}, \beta_{H}^{n}$ and $\beta_{E}^{n}$ estimates for the private and for the public sectors. Estimates for the dynamic model in column 2 shows that a $10 \%$ increase in the real minimum wage increases (decreases) total employment by $0.09 \%(0.31 \%)$ in the private (public) sector, decomposed into a $0.10 \%(0.32 \%)$ increase (decrease) in the number of hours worked and a $0.01 \%(0.01 \%)$ decrease (increase) in the number of jobs. After two years of adjustments, total employment decreases (increases) by $0.06 \%(0.66 \%)$. Nonetheless, only the long run estimates are significant. This suggests that the minimum wage does not effect employment in the short run in either sector. In the long run, the minimum wage decreases employment in the private sector, mainly via a decrease in the number of hours worked. In the public sector, even in the long run, no evidence of adverse employment effect was uncovered, suggesting an inelastic labour demand curve.

Thus, despite of sizeable wage effects in both sectors, adverse employment effects are small. They are also small when compared to the $-1 \%$ (overall) employment effect in the

\footnotetext{
${ }^{5}$ To preserve the decomposition, lagged $T$, which embodies the variation of $H$ and $E$, was used in all three equations.
} 
international literature, but in line with previous (overall) employment effect evidence for Brazil (see Section 1). Lemos (2004) found less negative overall long run total employment effect in Brazil, suggesting that the non-negative effect in the public sector offsets some of the negative effect in the private sector, diluting the overall effect. Neumark et al. (2003) and Fajnzylber (2001) also estimate small employment effects in Brazil, but both use different data partitions (formal and informal) and the first uses a different data period (low inflation), which make their results not directly comparable with the above results.

Although these results are in line with other overall employment effect evidence, there is neither a specific theory that predicts such results nor available empirical evidence across the private and public sectors in the Brazilian or international literature to compare these results with. However, they are intuitive and can be argued to be loosely in line with theory. This is because theory predicts a stronger effect on population groups where the minimum wage is more binding. In that sense, evidence of a stronger compression effect and more adverse employment effects in the private sector is consistent with theory.

\section{Conclusion}

This paper estimates the effects of the minimum wage on wages and employment in the private and public sectors in Brazil. The minimum wage was found to compress the wage distribution of both sectors. In the private sector, consistent with the presence of a larger spike, larger spillover effects, and a stronger compression effect, more adverse long run total employment effects were also observed. In the public sector, no evidence of adverse employment effects was uncovered, suggesting an inelastic labour demand curve. This is supporting evidence that a Government employer does not respond to a minimum wage increase in the same way that a profit maximising firm does.

The evidence in this paper suggests that the associated non-negative employment effect 
in the public sector offsets some of the negative employment effect observed in the private sector, diluting the overall employment effect to be less adverse than the later. Taking the overall employment effect as an estimate of the effect on the private sector might mislead policymakers to increase the minimum wage more generously than they would otherwise do. More generally, the policymaking significance of these findings is that policymakers can use minimum wage laws to fight poverty and inequality without destroying too many jobs in Brazil. Nonetheless, such laws will increase the public deficit - uncontrollably large and growing in Brazil, as it is often the case in developing countries - which might undermine the fight against poverty and inequality. Incidentally, studying the effect of the minimum wage on the public deficit (via benefits, pensions, and the wage bill) might be a fruitful avenue for research. 


\section{References}

[1] BELL, L. A. (1997): "The Impact of Minimum Wages in Mexico and Colombia," Journal of Labour Economics, 15, S102-S135.

[2] BROWN, C. (1999): "Minimum Wages, Employment, and the Distribution of Income," in Handbook of Labour Economics, ed. by O. Ashenfelter, and D. Card. Amsterdam; New York and Oxford: Elsevier Science, North-Holland, 2101-2163.

[3] Burkhauser, R. V., K. A. COUCH, and D. C. WittenburG (2000): "A Reassessment of the New Economics of the Minimum Wage Literature with Monthly Data from the Current Population Survey," Journal of Labour Economics, 18, 653-680.

[4] CARD, D. (1992): "Do Minimum Wages Reduce Employment? A Case Study of California, 1987-89," Industrial and Labour Relations Review, 46, 38-54.

[5] CARD, D. E., and A. B. KRUEGER (1995): Myth and Measurement: The New Economics of the Minimum Wage. Princeton: Princeton University Press.

[6] CARD, D. E., and A. B. KRUEGER (2000): "Minimum Wages and Employment: A Case Study of the Fast-Food Industry in New Jersey and Pennsylvania: Reply," American Economic Review, 90, 1397-1420.

[7] CASTILlo FREEMAN, A. J., and R. B. FREEMAN (1992): "When the Minimum Wage Really Bites: The Effect of the U.S.-Level Minimum on Puerto Rico," in Immigration and the Work Force: Economic Consequences for the United States and Source Areas, ed. by G. J. Borjas, and R. B. Freeman. Chicago and London: University of Chicago Press, 177-211.

[8] DICKENS, R., S. MACHIN, and A. MANNING (1999): "The Effects of Minimum Wages on Employment: Theory and Evidence from Britain," Journal of Labour Economics, 17, 1-22. 
[9] DOLADO, J., and ET AL. (1996): "The Economic Impact of Minimum Wages in Europe," Economic Policy: A European Forum, 23, 317-357.

[10] FAJNZYLBER, P. (2001): "Minimum Wage Effects Throughout the Wage Distribution: Evidence from Brazil's Formal and Informal Sectors," Anais do XXIX Encontro Nacional de Economia.

[11] LEMOS, S. (2004): "Are Wage and Employment Effects Robust to Alternative Minimum Wage Variables?", IZA Discussion Paper, 1070.

[12] MACHIN, S., A. MANNING, and L. RAHMAN (2003): "Where the Minimum Wage Bites Hard: Introduction of Minimum Wages to a Low Wage Sector," Journal of The European Economic Association, Inaugural Issue, 154-180.

[13] MALONEY, W., and J. MENDEZ (2004): "Minimum Wages in Latin America," in Law and Employment: Lessons from Latin America and the Caribbean, ed. by J. Heckman, and C. Pagés. Cambridge, MA: NBER and University of Chicago.

[14] MOnTEnEGRO, C., and C. PAGÉS (2004): "Who Benefits from Labour Market Regulations? Chile 1960-1998," in Law and Employment: Lessons from Latin America and the Caribbean, ed. by J. Heckman, and C. Pagés. Cambridge, MA: NBER and University of Chicago.

[15] NEUMARK, D., W. CUNNINGHAM, and L. SIGA (2003): "The Distributional Effects of Minimum Wages in Brazil: 1996-2001," Unpublished Paper.

[16] NEUMARK, D., and W. WASCHER (1992): "Employment Effects of Minimum and Subminimum Wages: Panel Data on State Minimum Wage Laws," Industrial and Labour Relations Review, 46, 55-81. 
[17] NEUMARK, D., and W. WASCHER (2000): "Minimum Wages and Employment: A Case Study of the Fast-Food Industry in New Jersey and Pennsylvania: Comment," American Economic Review, 90, 1362-1396.

[18] WELCH, F. R., and J. CUNNINGHAM (1978): "Effects of Minimum Wages on the Level and Age Composition of Youth Employment," Review of Economics and Statistics, 60, 140-145.

[19] WILLIAMS, N. (1993): "Regional Effects of the Minimum Wage on Teenage Employment," Applied Economics, 25, 1517-1528. 
PRIVATE AND PUBLIC SECTORS 1982 to 2000

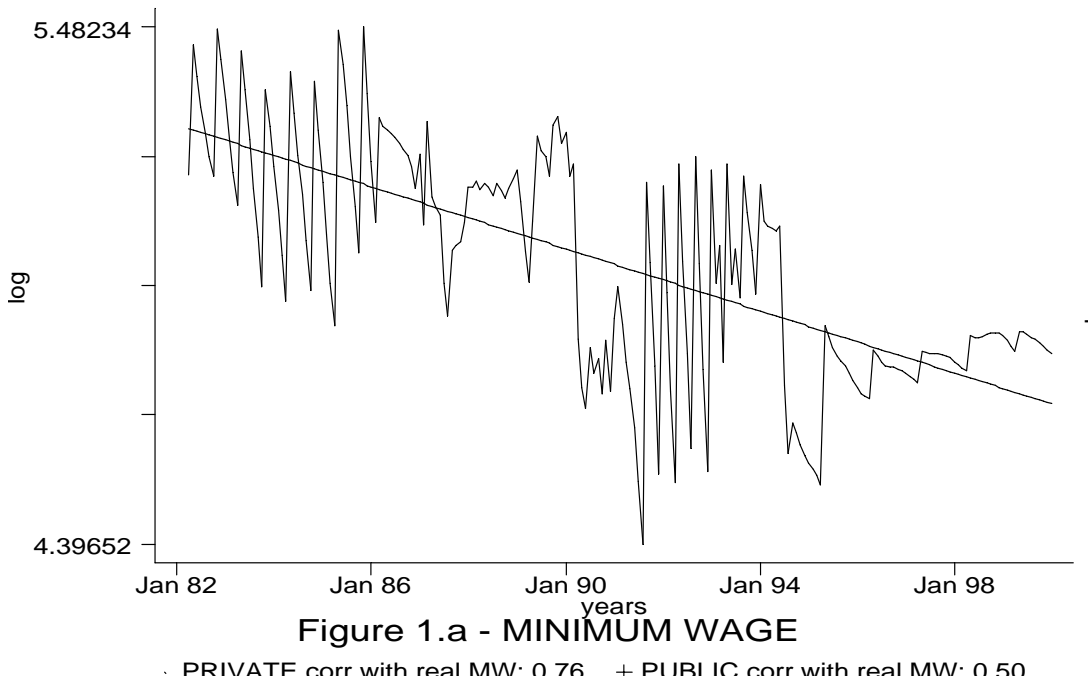

PRIVATE corr with real MW: 0.76 + PUBLIC corr with real MW: 0.50

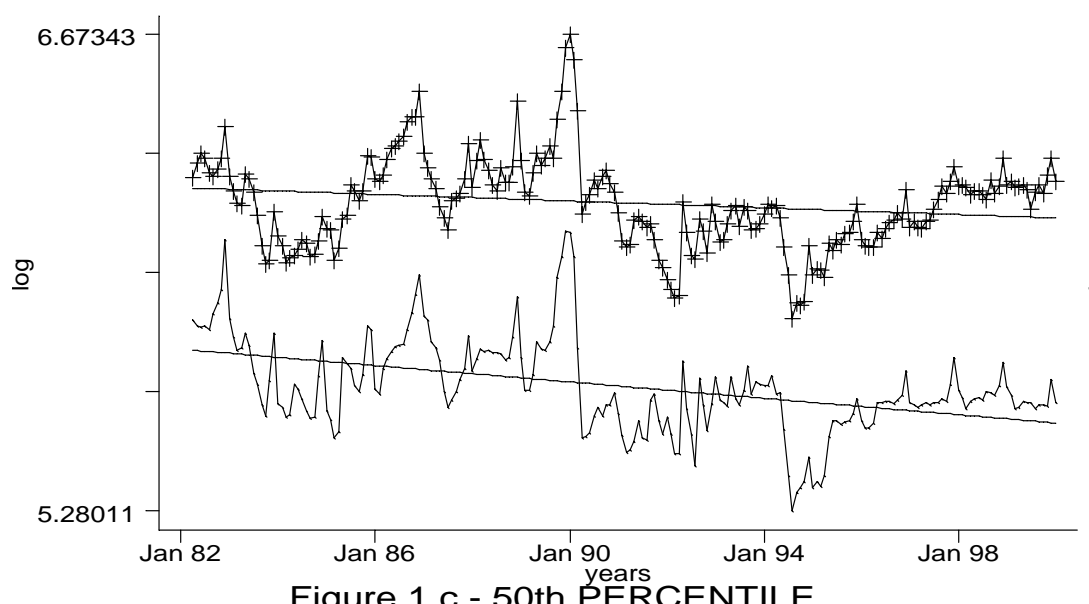

PRIVATE corr with real MW: 0.86 + PUBLIC corr with real MW: 0.66
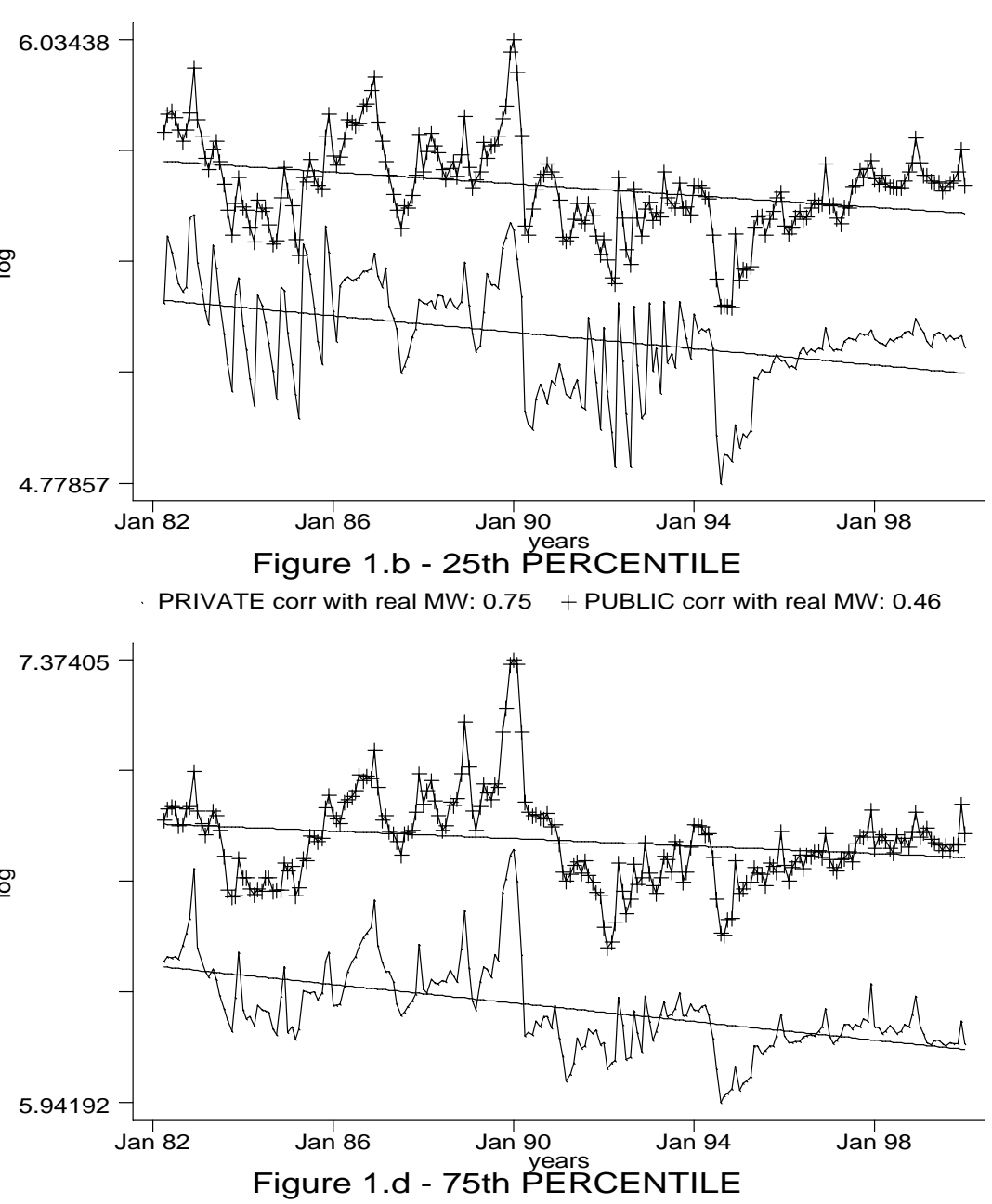

=igure 1 - MINIMUM WAGE AND EARNINGS DISTRIBUTION PERCENTILE RATIOS 
PRIVATE SECTOR January to December 1992

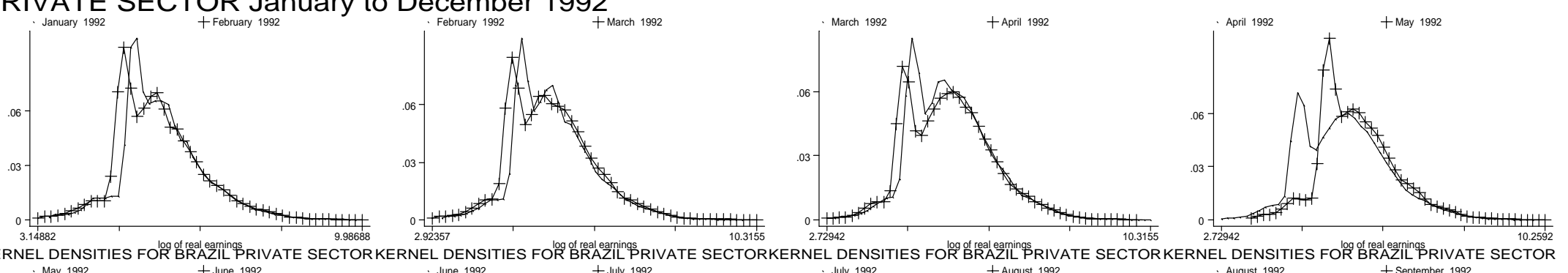

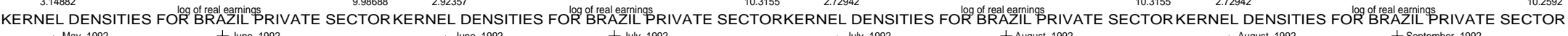
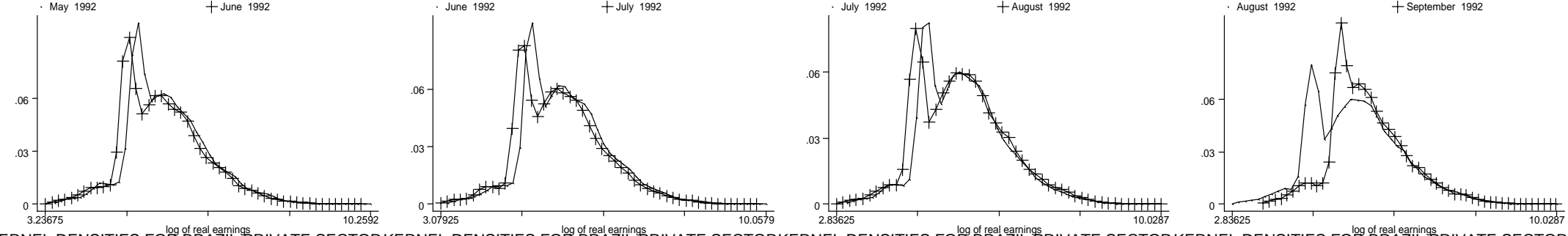

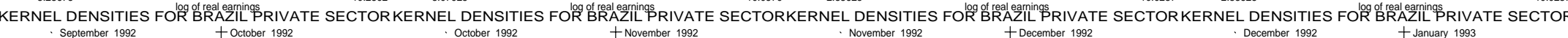
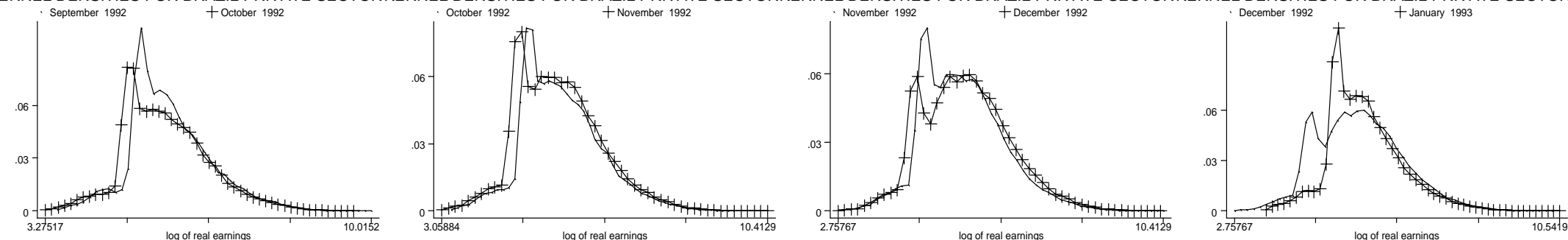

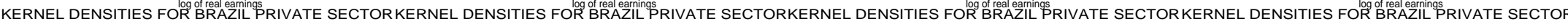

Figure 2.a - KERNEL EARNINGS DISTRIBUTIONS 
PUBLIC SECTOR January to December 1992
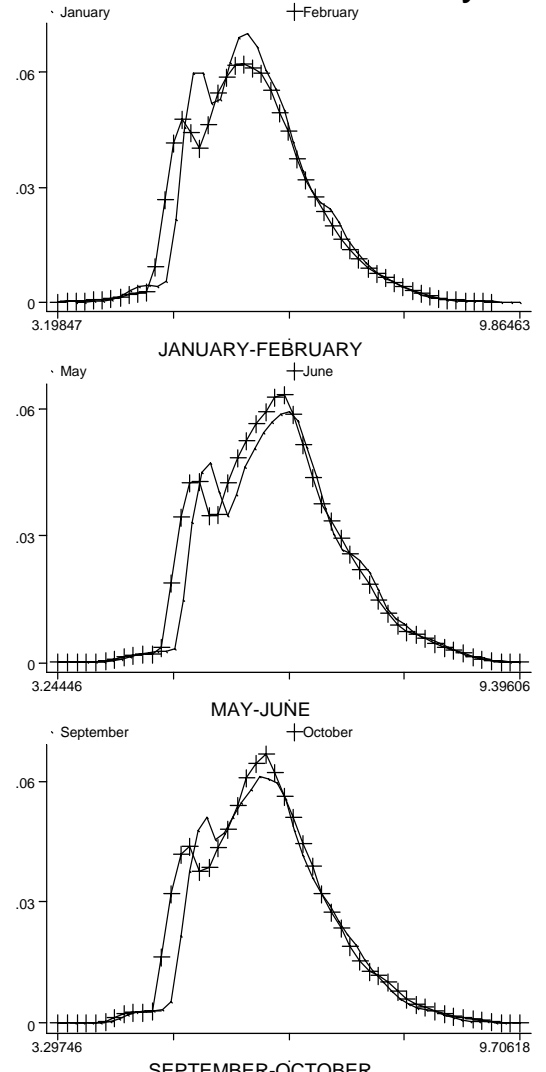

SEPTEMBER-OCTOBER
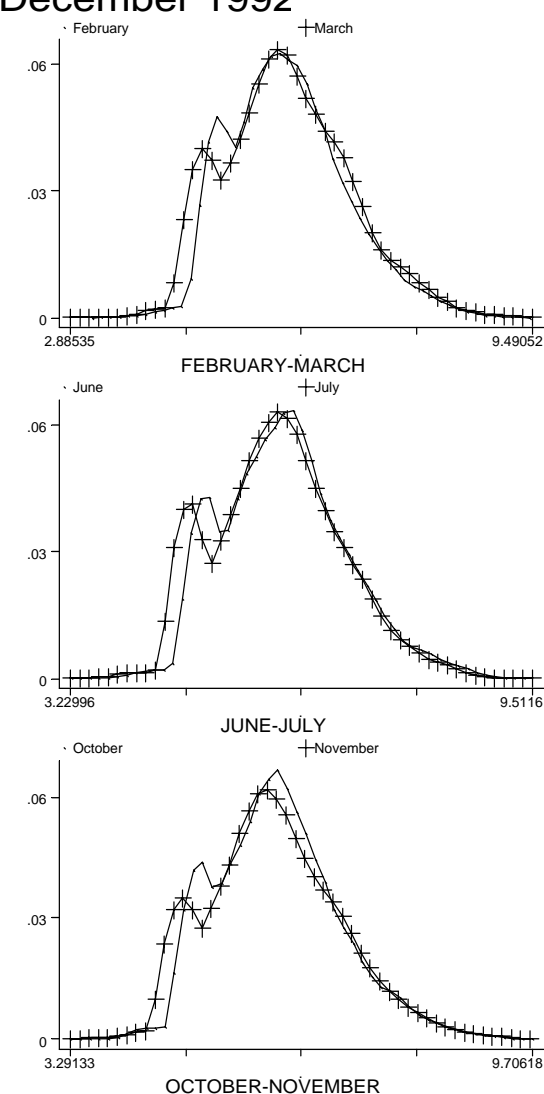

OCTOBER-NOVEMBER
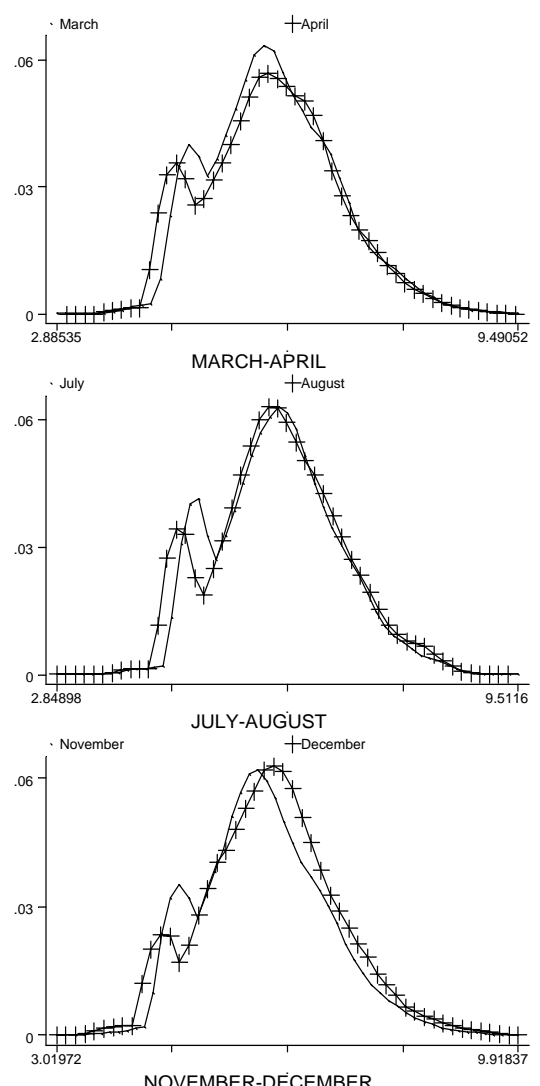

NOVEMBER-DECEMMBER
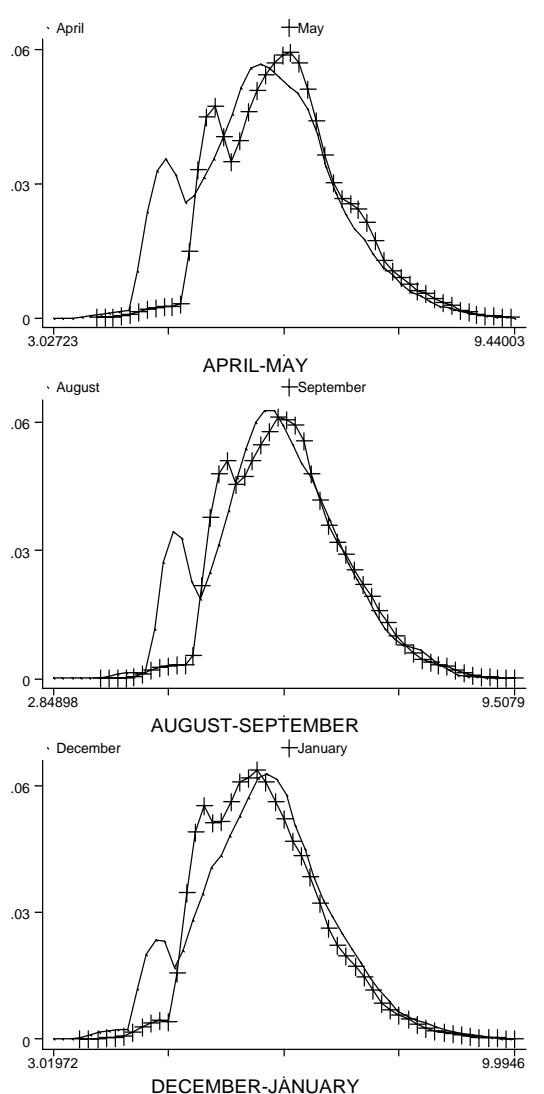

Figure 2.b - KERNEL EARNINGS DISTRIBUTIONS 
PRIVATE AND PUBLIC SECTORS 1982 to 2000

PRIVATE: corr with real MW: 0.41 + PUBLIZ: corr with real MW: -0.09

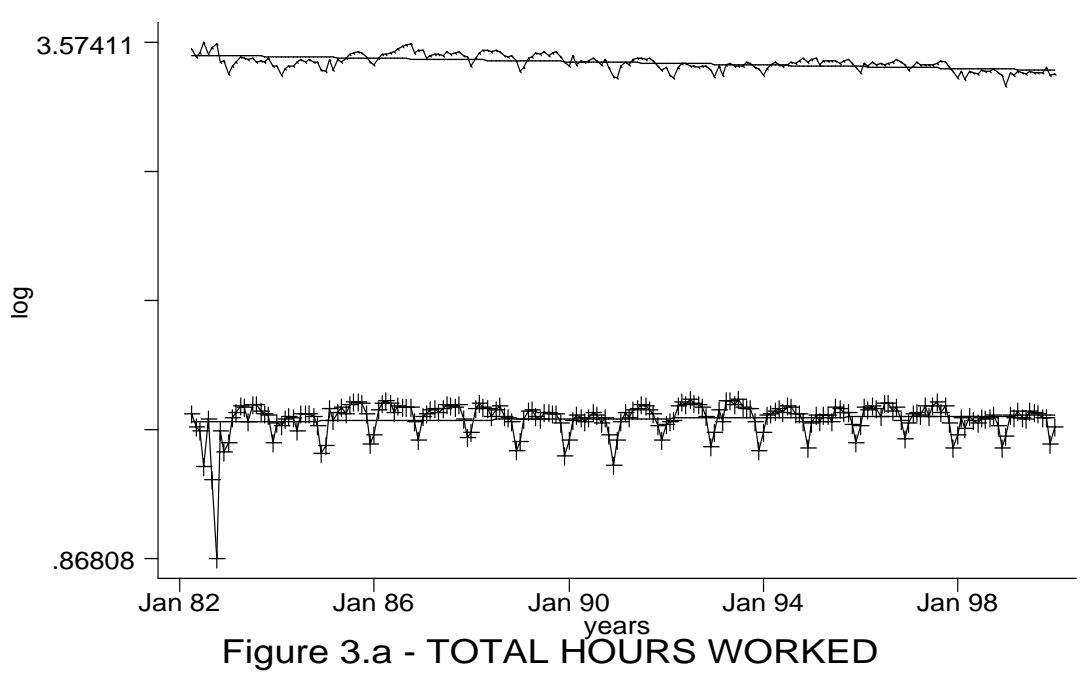

PRIVATE: corr with real MW: 0.19 + PUBLIZ: corr with real MW: -0.01

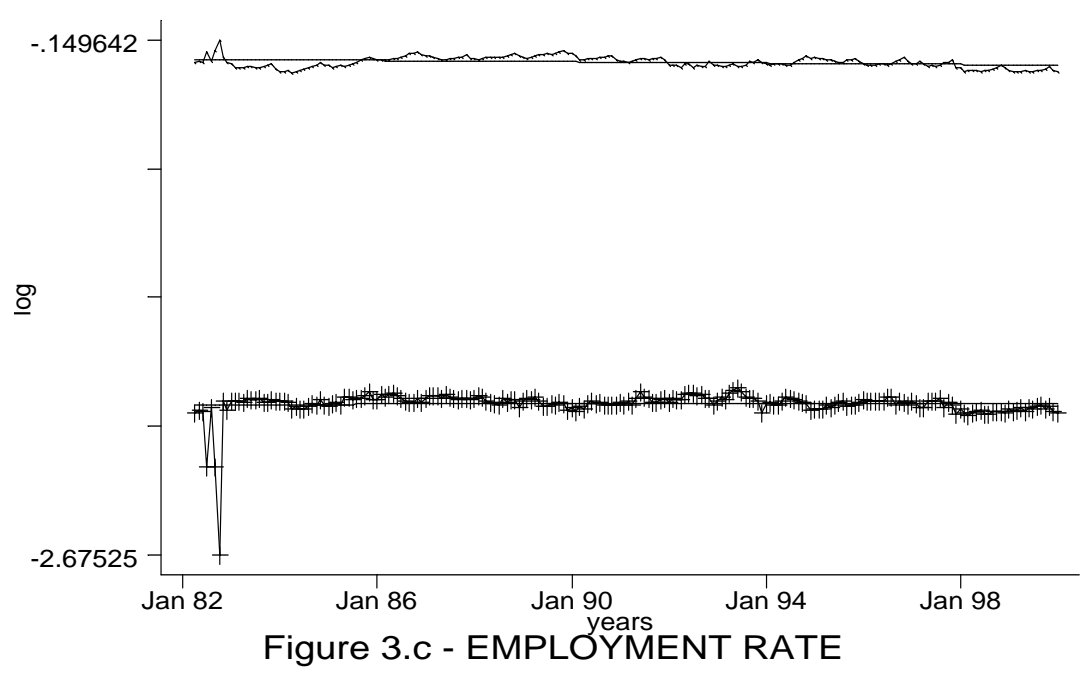

PRIVATE: corr with real MW: 0.38 + PUBLIZ: corr with real MW: -0.12

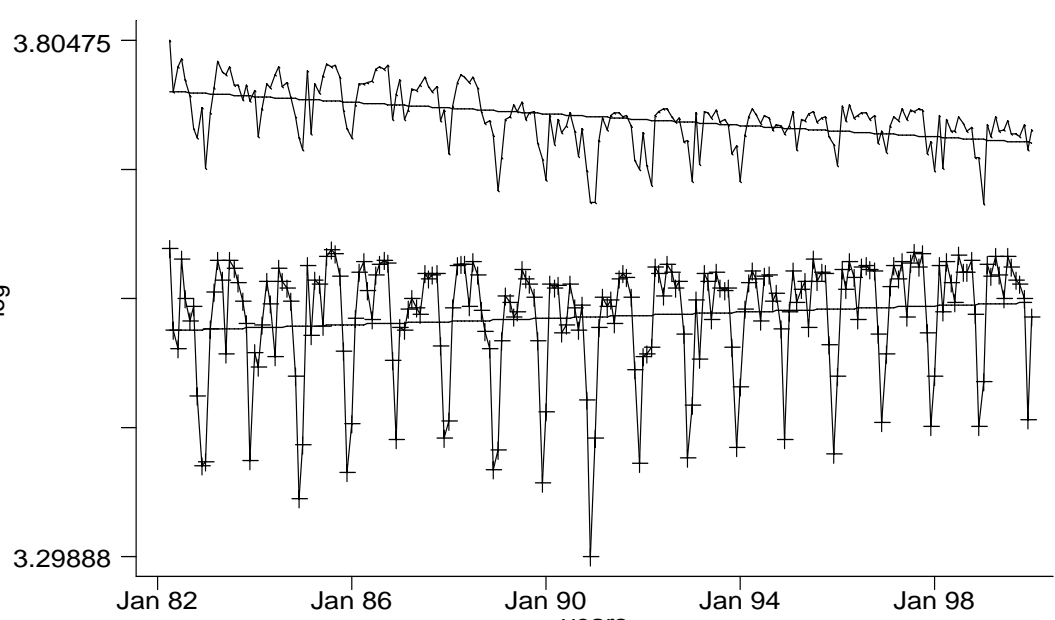

Figure 3.b - HOURS WORKED BY THOSE WORKING

Figure 3 - HOURS WORKED AND EMPLOYMENT RATE 
Table 1 - EFFECT OF A 10\% INCREASE IN THE MINIMUM WAGE ON WAGES

\begin{tabular}{lcccc}
\hline percentiles & \multicolumn{2}{c}{ coef } & se & coef \\
\hline & A - private sector & B - public sector \\
5th percentile & $\mathbf{- 0 . 1 8}$ & 0.36 & $\mathbf{4 . 6 4}$ & 0.47 \\
10th percentile & $\mathbf{1 . 5 0}$ & 0.33 & $\mathbf{5 . 2 6}$ & 0.50 \\
15th percentile & $\mathbf{4 . 6 8}$ & 0.35 & $\mathbf{4 . 7 0}$ & 0.47 \\
20th percentile & $\mathbf{5 . 7 1}$ & 0.36 & $\mathbf{3 . 9 4}$ & 0.47 \\
25th percentile & $\mathbf{5 . 4 7}$ & 0.35 & $\mathbf{3 . 0 8}$ & 0.44 \\
30th percentile & $\mathbf{4 . 9 8}$ & 0.36 & $\mathbf{2 . 6 1}$ & 0.42 \\
35th percentile & $\mathbf{4 . 2 0}$ & 0.34 & $\mathbf{2 . 9 1}$ & 0.40 \\
40th percentile & $\mathbf{3 . 5 2}$ & 0.32 & $\mathbf{2 . 3 8}$ & 0.42 \\
45th percentile & $\mathbf{2 . 9 1}$ & 0.28 & $\mathbf{2 . 1 8}$ & 0.46 \\
50th percentile & $\mathbf{2 . 5 4}$ & 0.29 & $\mathbf{1 . 7 1}$ & 0.45 \\
90th percentile & $\mathbf{0 . 3 2}$ & 0.38 & $\mathbf{0 . 9 0}$ & 0.55 \\
95th percentile & $\mathbf{0 . 0 4}$ & 0.42 & $\mathbf{0 . 1 8}$ & 0.63 \\
mean & $\mathbf{2 . 2 5}$ & 0.23 & $\mathbf{2 . 2 6}$ & 0.33 \\
90th/10th percentile ratio & $\mathbf{- 1 . 1 7}$ & 0.48 & $\mathbf{- 4 . 5 2}$ & 0.66 \\
90th/50th percentile ratio & $\mathbf{- 2 . 2 2}$ & 0.34 & $\mathbf{- 0 . 8 2}$ & 0.51 \\
50th/10th percentile ratio & $\mathbf{1 . 0 9}$ & 0.37 & $\mathbf{- 3 . 6 3}$ & 0.51 \\
standard deviation & $\mathbf{0 . 9 0}$ & 0.11 & $\mathbf{- 0 . 8 8}$ & 0.17
\end{tabular}

(a) Panels A and B show respectively GLS estimates (coef) of "fraction affected" for the private and public sectors, where the weights are the square root of the inverse of the sample size. Standard errors (se) are White-corrected and serial correlation corrected across and within regions (assuming an autoregressive process specific to each region)

(b) The dependent variable is, in turn, various percentiles, ratios of percentiles and standard deviation of the wages distribution.

(c) Time effects are modeled with month dummies, region effects are modeled with region dummies, and labor supply shifter are included as controls.

(d) To reflect a $10 \%$ increase in the minimum wage, the estimates and standard errors were multiplied by 4.5 , which is the approximate elasticity of the minimum wage with respect to "fraction affected". 
Table 2 - EFFECT OF A 10\% INCREASE IN THE MINIMUM WAGE ON EMPLOYMENT

\begin{tabular}{|c|c|c|c|c|c|c|c|c|c|c|c|c|}
\hline \multirow[b]{2}{*}{$\begin{array}{l}\text { dependent } \\
\text { variable } \\
\end{array}$} & \multirow{2}{*}{$\begin{array}{r}\text { static } \\
\text { sr coef } \\
(1) \\
\end{array}$} & \multicolumn{3}{|c|}{ dynamic } & \multirow{2}{*}{$\begin{array}{r}\text { lr } \\
\text { Ir coef } \\
(3) \\
\end{array}$} & \multirow[b]{2}{*}{ se } & \multirow{2}{*}{$\begin{array}{r}\text { static } \\
\text { coef } \\
(1) \\
\end{array}$} & \multicolumn{2}{|c|}{ dynamic } & \multicolumn{3}{|c|}{$l r$} \\
\hline & & se & $\begin{array}{r}\text { sr coef } \\
(2) \\
\end{array}$ & se & & & & se & $\begin{array}{r}\text { coef } \\
(2) \\
\end{array}$ & se & $\begin{array}{r}\text { coef } \\
(3) \\
\end{array}$ & se \\
\hline & \multicolumn{6}{|c|}{ A - private sector } & \multicolumn{6}{|c|}{ B - public sector } \\
\hline total employment & 0.13 & 0.11 & 0.09 & 0.09 & -0.06 & 0.00 & -0.01 & 0.22 & -0.31 & 0.21 & 0.66 & 0.01 \\
\hline hours worked & 0.13 & 0.10 & 0.10 & 0.08 & -0.11 & 0.00 & -0.03 & 0.21 & -0.32 & 0.19 & 1.59 & 0.01 \\
\hline employment rate & 0.00 & 0.04 & -0.01 & 0.04 & -0.01 & 0.00 & 0.02 & 0.06 & 0.01 & 0.06 & 0.03 & 0.00 \\
\hline
\end{tabular}

(a) Panels A and B show respectively GLS estimates (coef) of the "traction affected" tor the private and public sectors where the weights are the square root of the inverse of the sample size. Standard errors (se) are White-corrected

and serial correlation corrected across and within regions (assuming an autoregressive process specitic to each region)

(b) Column 1 shows the base specitication with past intlation, controls, region and time tixed ettects; and column 2 adds dynamics to the base specitication ( 24 lags of the independent variable). Column 3 shows the long run coetticient associated to the short run coetticient in column 2.

(c) The dependent variable is, in turn, average hours worked tor the labor torce, average hours worked tor those employed and employment rate. Hours and Job elasticities add to Iotal elasticity.

(d) lime eftects are modeled with month dummies, region ettects are modeled with region dummies, and labor supply shitters are included as control

(e) To retlect a $10 \%$ increase in the minimum wage, the estimates and standard errors were multiplied by $4 . b$, which is the approximate elasticity of the minimum wage with respect to "traction atfected". 


\title{
Appendix NOT FOR INCLUSION IN PUBLISHED VERSION
}

\author{
For referees' information only
}

\section{A Definition of Controls}

Young - Proportion of the population between 10 and 25 years of age, calculated using the reported date of birth at the time of the interview.

Younger than 10 years old - Proportion of the population younger than 10 years of age, calculated using the reported date of birth at the time of the interview.

Illiterate - Proportion of the population self-reported as "not knowing how to read and write".

Retiree - Proportion of the population self-reported as retired.

Student - Proportion of the population self-reported as students.

In urban areas - Proportion of the population with addresses in urban areas.

Working in the public sector - Proportion of the population self-reported as working as civil servants on municipal, state or federal employment.

Working in the informal sector - Proportion of the population self-reported as working without a signed labour contract card.

Working in the building construction industry - Proportion of the population selfreported as working in the building construction industry.

Working in the metallurgic industry - Proportion of the population self-reported as working in the metallurgic industry.

Basic education degree holders - Proportion of the population self-reported with 8 years of formal education. 
High school degree holders - Proportion of the population self-reported with 11 years of formal education.

Working on two jobs - Proportion of the population self-reported with a second job.

\section{B. Elasticity of "Fraction at" with respect to the Nom- inal Minimum Wage}

To reflect a $10 \%$ increase in the minimum wage, the "fraction at" estimates are multiplied by 4.5 , which is the approximate elasticity of the "fraction affected" with respect to the real minimum wage. The 4.5 estimate is the coefficient of the real minimum wage on a regression of "fraction affected" on the difference of log real minimum wage and the other regressors in Equation (1). This estimate was robust to using the regressors in Equations (2) and (2') instead. The intuition is given by a deterministic model where $y=a_{1}+b_{1} x, y=a_{2}+b_{2} z$, $z=a_{3}+b_{3} x$ and $b_{1}=b_{2} b_{3}, \forall b_{1}, b_{2}, b_{3} \neq 0$. Table B shows that the 4.5 estimate was remarkably robust across specifications. Table B.1 shows the full regression output when using the controls for the dynamic employment model, Equation (2').

\section{Regression Output}

\section{C.1 Wage Effect}

Table C.1 shows the full regression output for Equation (1) where $W_{r t}$ is defined as real hourly average wages (corresponding to row 13, panel A of Table 1).

\section{C.2 Employment Effect}

Table C.2 shows the full regression output for Equation (2') where $N_{r t}$ is defined as average hours in the population (corresponding to row 1, column 2, panel A of Table 2). 
Table B - ELASTICITY OF "FRACTION AFFECTED" W.R.T. THE MINIMUM WAGE (across models)

\begin{tabular}{|c|c|c|}
\hline \multirow[t]{2}{*}{ model } & \multicolumn{2}{|l|}{ MW } \\
\hline & $\begin{array}{r}\text { coef } \\
(1)\end{array}$ & se \\
\hline $\begin{array}{l}\text { using controls from the: } \\
\text { wage models } \\
\text { employment models }\end{array}$ & 0.446 & 0.136 \\
\hline $\begin{array}{l}\text { static } \\
\text { dynamic }\end{array}$ & $\begin{array}{l}0.438 \\
0.470\end{array}$ & $\begin{array}{l}0.136 \\
0.147\end{array}$ \\
\hline
\end{tabular}

(a) GLS estimates (coefficient), where the weights are the square root of the inverse of the sample size. Standard errors (se) are White-corrected and serial correlation corrected across and within regions (assuming an autoregressive process specific to each region).

(b) The dependent variable is "fraction affected".

The independent variable of interest is the real minimum wage

(c) Time effects are modeled with month dummies, region effects are modelled with region dummies, and labor supply shifters and aggregate demand shifters are included as controls where appropriate.

(d) Table C.1 shows full results for the dynamic employment model, which is one example of the above models. 
Table B.1 - ELASTICITY OF "FRACTION AFFECTED" W.R.T. THE MINIMUM WAGE (dynamic employment model)

\begin{tabular}{|c|c|c|}
\hline Independent Variables & coef & se \\
\hline fraction affected & 0.470 & 0.147 \\
\hline past inflation & 0.076 & 0.121 \\
\hline \% young & 0.025 & 0.329 \\
\hline \% younger than 10 years old & 0.155 & 0.148 \\
\hline \% women & -0.663 & 0.243 \\
\hline \% illiterate & 0.239 & 0.431 \\
\hline \% student & 0.467 & 0.277 \\
\hline$\%$ retiree & 0.710 & 0.331 \\
\hline$\%$ in urban areas & 0.445 & 0.285 \\
\hline \% working in the informal sector & -0.237 & 0.249 \\
\hline$\%$ working in the public sector (municipal and estate jobs) & 0.552 & 0.467 \\
\hline$\%$ working in the public sector (federal jobs) & 1.478 & 0.875 \\
\hline$\%$ workers in the building construction industry & 0.121 & 0.464 \\
\hline$\%$ workers in the metallurgic industry & 1.239 & 0.350 \\
\hline \% working on two jobs & 0.594 & 0.719 \\
\hline$\%$ with basic ( 8 years of) education & -0.065 & 0.284 \\
\hline$\%$ with high (11 years of) education & 0.527 & 0.339 \\
\hline average years of education & 0.152 & 0.436 \\
\hline regional dummy for Pernambuco & 0.004 & 0.002 \\
\hline regional dummy for Minas Gerais & 0.005 & 0.002 \\
\hline regional dummy for Rio de Janeiro & 0.009 & 0.002 \\
\hline regional dummy for Sao Paulo & 0.014 & 0.004 \\
\hline regional dummy for Rio Grande do Sul & 0.008 & 0.003 \\
\hline constant & -0.021 & 0.007 \\
\hline 1st lag of total employment & -0.164 & 0.064 \\
\hline 2nd lag of total employment & 0.047 & 0.071 \\
\hline 3rd lag of total employment & -0.137 & 0.075 \\
\hline 4th lag of total employment & -0.011 & 0.077 \\
\hline 5th lag of total employment & -0.042 & 0.080 \\
\hline 6th lag of total employment & 0.037 & 0.083 \\
\hline 7th lag of total employment & 0.155 & 0.084 \\
\hline 8th lag of total employment & 0.139 & 0.085 \\
\hline 9th lag of total employment & 0.107 & 0.086 \\
\hline 10th lag of total employment & 0.090 & 0.086 \\
\hline 11th lag of total employment & 0.080 & 0.085 \\
\hline 12th lag of total employment & 0.114 & 0.086 \\
\hline 13th lag of total employment & 0.142 & 0.086 \\
\hline 14th lag of total employment & 0.130 & 0.086 \\
\hline 15th lag of total employment & 0.093 & 0.087 \\
\hline 16th lag of total employment & -0.007 & 0.086 \\
\hline 17th lag of total employment & -0.066 & 0.085 \\
\hline 18th lag of total employment & 0.014 & 0.084 \\
\hline 19th lag of total employment & -0.074 & 0.084 \\
\hline 20th lag of total employment & -0.117 & 0.082 \\
\hline 21st lag of total employment & -0.055 & 0.080 \\
\hline 22nd lag of total employment & 0.068 & 0.079 \\
\hline 23rd lag of total employment & 0.007 & 0.073 \\
\hline 24th lag of total employment & -0.003 & 0.068 \\
\hline time dummy for June of 1986 & -0.037 & 0.011 \\
\hline time dummy for July of 1986 & -0.040 & 0.012 \\
\hline time dummy for August of 1986 & -0.046 & 0.010 \\
\hline time dummy for September of 1986 & -0.033 & 0.012 \\
\hline time dummy for October of 1986 & -0.035 & 0.011 \\
\hline time dummy for November of 1986 & -0.025 & 0.011 \\
\hline time dummy for December of 1986 & -0.028 & 0.012 \\
\hline time dummy for January of 1987 & 0.047 & 0.018 \\
\hline time dummy for February of 1987 & 0.003 & 0.021 \\
\hline time dummy for March of 1987 & -0.025 & 0.047 \\
\hline time dummy for April of 1987 & 0.001 & 0.023 \\
\hline time dummy for May of 1987 & -0.038 & 0.023 \\
\hline time dummy for June of 1987 & -0.039 & 0.028 \\
\hline time dummy for July of 1987 & -0.014 & 0.025 \\
\hline time dummy for August of 1987 & -0.030 & 0.018 \\
\hline time dummy for September of 1987 & 0.009 & 0.029 \\
\hline time dummy for October of 1987 & 0.058 & 0.013 \\
\hline time dummy for November of 1987 & 0.032 & 0.014 \\
\hline time dummy for December of 1987 & 0.018 & 0.022 \\
\hline
\end{tabular}


time dummy for January of 1988

time dummy for February of 1988

0.011

time dummy for March of 1988

time dummy for April of 1988

time dummy for May of 1988

time dummy for June of 1988

time dummy for July of 1988

time dummy for August of 1988

time dummy for September of 1988

time dummy for October of 1988

time dummy for November of 1988

time dummy for December of 1988

time dummy for January of 1989

time dummy for February of 1989

time dummy for March of 1989

time dummy for April of 1989

time dummy for May of 1989

time dummy for June of 1989

time dummy for July of 1989

time dummy for August of 1989

time dummy for September of 1989

time dummy for October of 1989

time dummy for November of 1989

time dummy for December of 1989

time dummy for January of 1990

time dummy for February of 1990

time dummy for March of 1990

time dummy for April of 1990

time dummy for May of 1990

time dummy for June of 1990

time dummy for July of 1990

time dummy for August of 1990

time dummy for September of 1990

time dummy for October of 1990

time dummy for November of 1990

time dummy for December of 1990

time dummy for January of 1991

time dummy for February of 1991

time dummy for March of 1991

time dummy for April of 1991

time dummy for May of 1991

time dummy for June of 1991

time dummy for July of 1991

time dummy for August of 1991

time dummy for September of 1991

time dummy for October of 1991

time dummy for November of 1991

time dummy for December of 1991

time dummy for January of 1992

time dummy for February of 1992

0.023

$\mathbf{0 . 0 3 8} \quad 0.024$

$\begin{array}{rl}\mathbf{- 0 . 0 3 4} & 0.021\end{array}$

$\mathbf{0 . 0 4 2} 0.026$

$\mathbf{- 0 . 0 2 1} 0.023$

$\mathbf{- 0 . 0 3 0} \quad 0.025$

$\mathbf{0 . 0 3 6} \quad 0.031$

$\mathbf{- 0 . 0 3 1} \quad 0.027$

$\mathbf{0 . 0 2 0} \quad 0.038$

$\mathbf{- 0 . 0 0 6} \quad 0.035$

$\mathbf{0 . 0 0 9} \quad 0.035$

$\mathbf{- 0 . 0 0 3} \quad 0.037$

$\mathbf{- 0 . 0 4 7} \quad 0.036$

$\mathbf{- 0 . 0 3 5} 0.029$

$\mathbf{- 0 . 0 1 3} 0.015$

$\mathbf{0 . 0 2 3} 0.026$

$\mathbf{0 . 0 2 6} \quad 0.038$

$\mathbf{- 0 . 0 1 8} \quad 0.029$

$\mathbf{- 0 . 0 0 5} \quad 0.036$

$\mathbf{- 0 . 0 2 8} \quad 0.035$

$\mathbf{0 . 0 3 6} 0.054$

$\mathbf{0 . 0 0 8} 0.047$

$\begin{array}{ll}\mathbf{- 0 . 0 3 8} & 0.049\end{array}$

$\mathbf{- 0 . 0 1 2} 0.062$

$\mathbf{- 0 . 0 5 6} \quad 0.068$

$\mathbf{- 0 . 0 1 4} \quad 0.090$

$\mathbf{- 0 . 0 1 7} \quad 0.080$

$\mathbf{- 0 . 0 6 1} \quad 0.049$

$\mathbf{- 0 . 0 2 8} \quad 0.015$

$\mathbf{0 . 0 5 0} \quad 0.030$

$\mathbf{- 0 . 0 1 0} \quad 0.015$

$\mathbf{0 . 0 1 0} 0.021$

$\mathbf{0 . 0 0 7} 0.016$

$\mathbf{0 . 0 3 8} 0.031$

$\mathbf{- 0 . 0 0 8} \quad 0.019$

$\mathbf{- 0 . 0 0 7} \quad 0.040$

$\mathbf{- 0 . 0 0 3} \quad 0.034$

$\mathbf{- 0 . 0 2 4} 0.024$

$\mathbf{- 0 . 0 2 3} \quad 0.018$

$\mathbf{0 . 0 0 5} 0.013$

$\mathbf{0 . 0 2 6} \quad 0.015$

$\mathbf{0 . 0 4 5} 0.017$

$\mathbf{0 . 0 3 9} \quad 0.019$

$\mathbf{- 0 . 1 1 6} \quad 0.124$

$\mathbf{- 0 . 0 1 4} 0.023$

$\mathbf{0 . 0 1 3} \quad 0.027$

$\mathbf{0 . 0 1 4} 0.031$

$\mathbf{- 0 . 0 8 7} \quad 0.110$

$\mathbf{- 0 . 0 2 8} 0.032$

$\mathbf{- 0 . 0 1 7} \quad 0.030$

$\mathbf{- 0 . 0 0 1} \quad 0.029$

$\mathbf{- 0 . 1 0 8} \quad 0.116$

$\mathbf{- 0 . 0 0 8} \quad 0.029$

$\mathbf{0 . 0 0 5} \quad 0.028$

$\mathbf{0 . 0 0 1} 0.029$

$\mathbf{- 0 . 0 6 6} \quad 0.109$

$\mathbf{0 . 0 2 5} 0.031$

$\mathbf{0 . 0 2 3} 0.032$

$\mathbf{0 . 0 1 0} \quad 0.031$

$\mathbf{- 0 . 1 1 2} \quad 0.112$

$\mathbf{0 . 0 0 4} 0.034$

$\mathbf{0 . 0 4 4} 0.042$

$\mathbf{- 0 . 0 0 7} \quad 0.034$

$\mathbf{- 0 . 0 1 7} \quad 0.086$

$\mathbf{- 0 . 0 1 4} \quad 0.035$

$\mathbf{0 . 0 0 8} \quad 0.043$

$\mathbf{- 0 . 0 4 2} \quad 0.033$

$\mathbf{- 0 . 0 0 3} \quad 0.069$

$\mathbf{- 0 . 0 5 9} \quad 0.038$

$\begin{array}{ll}-0.067 & 0.038\end{array}$

time dummy for October of 1993

$\mathbf{- 0 . 0 2 8} \quad 0.038$ 
time dummy for January of 1994

time dummy for February of 1994

$-0.011$

time dummy for March of 1994

time dummy for April of 1994

time dummy for May of 1994

time dummy for June of 1994

time dummy for July of 1994

time dummy for August of 1994

time dummy for September of 1994

time dummy for October of 1994

time dummy for November of 1994

0.069

time dummy for December of 1994

$\mathbf{- 0 . 0 4 1} \quad 0.042$

$\mathbf{0 . 0 4 4} 0.028$

$\mathbf{- 0 . 0 0 7} \quad 0.010$

$\mathbf{0 . 0 0 6} \quad 0.009$

$\mathbf{- 0 . 0 0 1} \quad 0.011$

time dummy for January of 1995

$\mathbf{0 . 0 0 3} 0.006$

time dummy for February of 1995

$\mathbf{- 0 . 0 0 1} \quad 0.012$

time dummy for March of 1995

time dummy for April of 1995

time dummy for May of 1995

time dummy for June of 1995

time dummy for July of 1995

time dummy for August of 1995

time dummy for September of 1995

time dummy for October of 1995

$\mathbf{- 0 . 0 1 0} \quad 0.009$

$\mathbf{- 0 . 0 0 7} \quad 0.010$

$\mathbf{- 0 . 0 3 7} \quad 0.053$

$\mathbf{- 0 . 0 1 6} \quad 0.009$

$\mathbf{0 . 0 0 3} \quad 0.010$

$\mathbf{- 0 . 0 0 5} \quad 0.009$

$\mathbf{- 0 . 0 0 3} \quad 0.009$

$\mathbf{0 . 0 1 2} 0.010$

$\begin{array}{rr}\mathbf{0 . 0 0 4} & 0.008 \\ \mathbf{- 0 . 0 0 1} & 0.009\end{array}$

time dummy for November of 1995

time dummy for January of 1996

time dummy for February of 1996

$\mathbf{- 0 . 0 0 6} \quad 0.009$

$\mathbf{- 0 . 0 0 5} \quad 0.010$

$\mathbf{0 . 0 0 8} \quad 0.010$

$\mathbf{- 0 . 0 0 8} 0.008$

$\mathbf{0 . 0 3 7} \quad 0.019$

$\mathbf{- 0 . 0 0 8} \quad 0.009$

$\mathbf{0 . 0 0 6} \quad 0.010$

$\mathbf{- 0 . 0 0 6} \quad 0.009$

$\mathbf{0 . 0 1 5} \quad 0.010$

$\mathbf{0 . 0 0 6} \quad 0.009$

$\mathbf{- 0 . 0 1 1} \quad 0.010$

$\mathbf{- 0 . 0 0 7} 0.008$

$\mathbf{0 . 0 0 2} 0.006$

$\mathbf{- 0 . 0 0 7} \quad 0.009$

$\mathbf{- 0 . 0 1 0} \quad 0.008$

$\begin{array}{ll}\mathbf{- 0 . 0 1 6} & 0.009\end{array}$

$\mathbf{0 . 0 0 2} 0.014$

$\mathbf{0 . 0 1 7} 0.009$

$\mathbf{0 . 0 0 8} 0.009$

$\mathbf{0 . 0 1 0} 0.009$

$\mathbf{0 . 0 1 1} 0.009$

$\mathbf{0 . 0 1 3} 0.009$

$\mathbf{0 . 0 0 7} 0.008$

$\begin{array}{ll}\mathbf{- 0 . 0 0 6} & 0.009\end{array}$

$\mathbf{- 0 . 0 0 6} \quad 0.007$

$\mathbf{- 0 . 0 0 3} 0.009$

$\mathbf{0 . 0 0 5} \quad 0.009$

$\begin{array}{ll}\mathbf{- 0 . 0 2 1} & 0.009\end{array}$

$\mathbf{0 . 0 2 6} \quad 0.016$

$\mathbf{- 0 . 0 1 2} 0.009$

$\mathbf{0 . 0 3 1} 0.010$

$\mathbf{0 . 0 2 5} \quad 0.010$

$\mathbf{0 . 0 2 9} \quad 0.010$

$\mathbf{0 . 0 4 5} \quad 0.012$

$\mathbf{0 . 0 1 8} 0.009$

$\mathbf{0 . 0 1 2} 0.010$

$\mathbf{0 . 0 0 0} \quad 0.008$

$\mathbf{- 0 . 0 0 2} \quad 0.010$

$\mathbf{0 . 0 1 4} 0.010$

$\mathbf{- 0 . 0 1 5} \quad 0.010$

$\mathbf{0 . 0 2 3} 0.013$

$\mathbf{0 . 0 0 0} \quad 0.010$

$\mathbf{0 . 0 0 3} 0.011$

$\mathbf{- 0 . 0 0 5} \quad 0.010$

$\mathbf{0 . 0 0 1} \quad 0.010$

$\mathbf{0 . 0 0 1} 0.011$

$\mathbf{0 . 0 0 1} 0.009$

$\begin{array}{lll}\text { time dummy for October of } 1999 & \mathbf{0 . 0 0 1} & 0.009 \\ \text { time dummy for November of } 1999 & \mathbf{0 . 0 0 4} & 0.011 \\ \text { time dummy for December of } 1999 & \end{array}$


number of observations per group 164

number of estimated coefficients $\quad 211$

$R$-squared

(a) GLS estimates (coef), where the weights are the square root of the inverse of the sample size. Standard errors (se) are White-corrected and serial correlation corrected across and within regions (assuming an autoregressive process specific to each region).

(b) The dependent variable is average hours worked for the labour force, which is one example of the employment equation estimated in the paper. The model is in differences. The minimum wage variable is "fraction affected"

(c) Time effects are modeled with month dummies, region effects are modelled with region dummies, and labour supply shifters are included as controls.

(d) To reflect a $10 \%$ increase in the minimum wage, the "fraction affected" estimate needs to be multiplied by 4.5 , which is the approximate elasticity of the minimum wage with respect to "fraction affected" 
Table C.1 - WAGE EQUATION

\begin{tabular}{|c|c|c|}
\hline Independent Variables & coef & se \\
\hline fraction affected & 0.500 & 0.051 \\
\hline past inflation & -0.422 & 0.104 \\
\hline past unemployment & -0.282 & 0.200 \\
\hline$\%$ young & -1.603 & 0.352 \\
\hline \% younger than 10 years old & -0.293 & 0.163 \\
\hline \% women & -0.063 & 0.268 \\
\hline \% illiterate & 0.845 & 0.466 \\
\hline$\%$ student & 1.778 & 0.282 \\
\hline$\%$ retiree & -0.112 & 0.380 \\
\hline$\%$ in urban areas & 0.290 & 0.317 \\
\hline$\%$ working in the informal sector & 0.751 & 0.256 \\
\hline$\%$ working in the public sector (municipal and estate jobs) & -0.296 & 0.519 \\
\hline \% working in the public sector (federal jobs) & 1.411 & 1.106 \\
\hline$\%$ workers in the building construction industry & -0.897 & 0.503 \\
\hline$\%$ workers in the metallurgic industry & 0.375 & 0.358 \\
\hline \% working on two jobs & 1.089 & 0.800 \\
\hline$\%$ with basic ( 8 years of) education & -1.480 & 0.315 \\
\hline$\%$ with high ( 11 years of) education & 0.315 & 0.371 \\
\hline average years of education & -0.890 & 0.463 \\
\hline regional dummy for Pernambuco & -0.001 & 0.002 \\
\hline regional dummy for Minas Gerais & 0.000 & 0.002 \\
\hline regional dummy for Rio de Janeiro & -0.002 & 0.003 \\
\hline regional dummy for Sao Paulo & -0.003 & 0.003 \\
\hline regional dummy for Rio Grande do Sul & -0.002 & 0.003 \\
\hline constant & -0.053 & 0.004 \\
\hline time dummy for July of 1984 & 0.108 & 0.010 \\
\hline time dummy for August of 1984 & 0.129 & 0.010 \\
\hline time dummy for September of 1984 & 0.081 & 0.010 \\
\hline time dummy for October of 1984 & 0.116 & 0.011 \\
\hline time dummy for November of 1984 & 0.149 & 0.017 \\
\hline time dummy for December of 1984 & 0.199 & 0.012 \\
\hline time dummy for January of 1985 & -0.019 & 0.011 \\
\hline time dummy for February of 1985 & 0.039 & 0.012 \\
\hline time dummy for March of 1985 & 0.169 & 0.012 \\
\hline time dummy for April of 1985 & 0.065 & 0.012 \\
\hline time dummy for May of 1985 & 0.201 & 0.018 \\
\hline time dummy for June of 1985 & 0.090 & 0.008 \\
\hline time dummy for July of 1985 & 0.114 & 0.009 \\
\hline time dummy for August of 1985 & 0.099 & 0.010 \\
\hline time dummy for September of 1985 & 0.106 & 0.012 \\
\hline time dummy for October of 1985 & 0.133 & 0.012 \\
\hline time dummy for November of 1985 & 0.184 & 0.016 \\
\hline time dummy for December of 1985 & 0.163 & 0.013 \\
\hline time dummy for January of 1986 & 0.023 & 0.015 \\
\hline time dummy for February of 1986 & 0.116 & 0.016 \\
\hline time dummy for March of 1986 & 0.081 & 0.016 \\
\hline time dummy for April of 1986 & 0.165 & 0.009 \\
\hline time dummy for May of 1986 & 0.108 & 0.005 \\
\hline time dummy for June of 1986 & 0.081 & 0.005 \\
\hline time dummy for July of 1986 & 0.121 & 0.005 \\
\hline time dummy for August of 1986 & 0.102 & 0.005 \\
\hline time dummy for September of 1986 & 0.109 & 0.005 \\
\hline time dummy for October of 1986 & 0.116 & 0.005 \\
\hline time dummy for November of 1986 & 0.151 & 0.005 \\
\hline time dummy for December of 1986 & 0.114 & 0.005 \\
\hline time dummy for January of 1987 & -0.054 & 0.007 \\
\hline time dummy for February of 1987 & 0.152 & 0.012 \\
\hline time dummy for March of 1987 & 0.058 & 0.017 \\
\hline time dummy for April of 1987 & 0.065 & 0.015 \\
\hline time dummy for May of 1987 & 0.112 & 0.018 \\
\hline time dummy for June of 1987 & 0.086 & 0.023 \\
\hline time dummy for July of 1987 & 0.110 & 0.023 \\
\hline time dummy for August of 1987 & 0.184 & 0.016 \\
\hline time dummy for September of 1987 & 0.104 & 0.009 \\
\hline time dummy for October of 1987 & 0.088 & 0.008 \\
\hline time dummy for November of 1987 & 0.144 & 0.010 \\
\hline time dummy for December of 1987 & 0.153 & 0.014 \\
\hline time dummy for January of 1988 & 0.069 & 0.016 \\
\hline time dummy for February of 1988 & 0.127 & 0.017 \\
\hline
\end{tabular}


time dummy for May of 1988

time dummy for December of 1988

time dummy for February of 1989

$\mathbf{0 . 1 2 8} 0.033$

time dummy for March of 1989

time dummy for April of 1989

time dummy for May of 1989

time dummy for June of 1989

time dummy for July of 1989

time dummy for August of 1989

time dummy for September of 1989

time dummy for October of 1989

time dummy for November of 1989

$\mathbf{0 . 1 4 2} 0.026$

$\mathbf{0 . 1 6 5} 0.012$

$\mathbf{0 . 1 0 2} 0.009$

$\mathbf{0 . 0 7 4} 0.014$

$\mathbf{0 . 1 6 4} 0.024$

$\mathbf{0 . 2 5 1} 0.030$

$\mathbf{0 . 1 9 7} 0.031$

$\mathbf{0 . 3 3 5} \quad 0.037$

$\mathbf{0 . 2 4 1} \quad 0.039$

time dummy for December of 1989

$\mathbf{0 . 3 1 2} 0.045$

$\mathbf{0 . 2 9 9} \quad 0.051$

time dummy for February of 1990

$\begin{array}{ll}\mathbf{0 . 2 9 9} & 0.061 \\ \mathbf{0 . 2 1 4} & 0.074\end{array}$

time dummy for March of 1990

time dummy for April of 1990

time dummy for May of 1990

time dummy for June of 1990

time dummy for July of 1990

time dummy for August of 1990

time dummy for September of 1990

time dummy for October of 1990

time dummy for November of 1990

$\mathbf{0 . 1 6 2} 0.081$

$\mathbf{0 . 2 7 8} \quad 0.045$

$\mathbf{0 . 1 0 0} 0.011$

$\mathbf{0 . 1 1 6} 0.012$

$\mathbf{0 . 1 5 6} 0.012$

$\mathbf{0 . 1 2 0} \quad 0.013$

$\mathbf{0 . 0 9 8} \quad 0.013$

$\mathbf{0 . 1 0 8} \quad 0.016$

$\begin{array}{ll}\mathbf{0 . 1 6 8} & 0.016 \\ \mathbf{0 . 1 1 1} & 0.019\end{array}$

time dummy for December of 1990

$\mathbf{0 . 0 3 8} \quad 0.021$

time dummy for March of 1991

$\mathbf{0 . 0 8 4} 0.021$

time dummy for April of 1991

time dummy for May of 1991

time dummy for June of 1991

time dummy for July of 1991

time dummy for August of 1991

time dummy for September of 1991

time dummy for October of 1991

time dummy for November of 1991

time dummy for December of 1991

$\mathbf{0 . 1 7 9} 0.016$

$\mathbf{0 . 1 2 6} 0.009$

$\mathbf{0 . 1 2 2} \quad 0.008$

$\mathbf{0 . 0 6 3} 0.010$

$\mathbf{0 . 1 0 4} 0.012$

$\mathbf{0 . 1 1 8} 0.020$

$\mathbf{0 . 1 6 1} 0.016$

$\mathbf{0 . 1 2 2} 0.019$

$\mathbf{0 . 1 2 5} 0.024$

$\mathbf{0 . 1 3 6} \quad 0.029$

time dummy for January of 1992

time dummy for February of 1992

0.029

time dummy for March of 1992

time dummy for April of 1992

time dummy for May of 1992

time dummy for June of 1992

time dummy for July of 1992

time dummy for August of 1992

time dummy for September of 1992

time dummy for October of 1992

time dummy for November of 1992

$\begin{array}{ll}\mathbf{0 . 1 9 6} & 0.026 \\ \mathbf{0 . 1 8 0} & 0.025\end{array}$

$\mathbf{0 . 1 0 0} 0.024$

$\mathbf{0 . 3 0 3} \quad 0.026$

$\mathbf{0 . 0 7 8} 0.023$

$\mathbf{0 . 0 9 5} \quad 0.023$

$\mathbf{0 . 1 5 0} 0.022$

$\mathbf{0 . 2 9 1} 0.026$

$\mathbf{0 . 1 0 8} 0.024$

$\mathbf{0 . 1 4 3} \quad 0.026$

$\mathbf{0 . 2 1 7} \quad 0.025$

$\mathbf{0 . 2 2 2} 0.028$

time dummy for January of 1993

time dummy for February of 1993

$\mathbf{0 . 0 7 2}-0.027$

time dummy for March of 1993

$\mathbf{0 . 2 1 5} 0.028$

time dummy for April of 1993

0.137

0.027

time dummy for May of 1993

time dummy for June of 1993

time dummy for July of 1993

time dummy for August of 1993

time dummy for September of 1993

time dummy for October of 1993

time dummy for November of 1993

time dummy for December of 1993

$\mathbf{0 . 1 8 0} \quad 0.031$

$\mathbf{0 . 1 3 5} \quad 0.028$

$\mathbf{0 . 1 6 8} \quad 0.030$

$\mathbf{0 . 2 6 1} 0.031$

$\mathbf{0 . 2 1 9} \quad 0.034$

$\mathbf{0 . 2 0 6} \quad 0.035$

$\mathbf{0 . 2 4 9}-0.036$

$\mathbf{0 . 1 9 5} \quad 0.036$

time dummy for January of 1994

$0.238 \quad 0.039$

time dummy for February of 1994

$\mathbf{0 . 2 1 3} 0.040$


time dummy for March of 1994

time dummy for April of 1994

time dummy for May of 1994

time dummy for June of 1994

time dummy for July of 1994

time dummy for August of 1994

$\mathbf{0 . 1 8 5} \quad 0.046$

time dummy for September of 1994

0.151

0.139

0.040

time dummy for October of 1994

0.017

time dummy for November of 1994

0.005

time dummy for December of 1994

$\mathbf{0 . 0 6 1} \quad 0.005$

time dummy for January of 1995

$\mathbf{0 . 1 3 1} 0.005$

time dummy for February of 1995

$\mathbf{0 . 0 0 7} 0.004$

time dummy for March of 1995

time dummy for April of 1995

time dummy for May of 1995

time dummy for June of 1995

time dummy for July of 1995

time dummy for August of 1995

time dummy for September of 1995

time dummy for October of 1995

time dummy for November of 1995

time dummy for December of 1995

$\mathbf{0 . 0 9 4} \quad 0.005$

$\mathbf{0 . 1 1 5} 0.004$

$\mathbf{0 . 0 5 8} \quad 0.004$

$\mathbf{0 . 1 3 4} 0.008$

$\mathbf{0 . 0 5 6} \quad 0.004$

$\mathbf{0 . 0 8 0} \quad 0.004$

$\mathbf{0 . 0 8 4} \quad 0.005$

$\mathbf{0 . 0 7 7} \quad 0.004$

$\mathbf{0 . 0 7 9} \quad 0.005$

$\mathbf{0 . 0 8 4} \quad 0.005$

$\mathbf{0 . 0 9 1} 0.005$

$\mathbf{0 . 0 5 5} \quad 0.003$

time dummy for January of 1996

time dummy for February of 1996

0.003

time dummy for March of 1996

time dummy for April of 1996

time dummy for May of 1996

time dummy for June of 1996

time dummy for July of 1996

time dummy for August of 1996

time dummy for September of 1996

time dummy for October of 1996

time dummy for November of 1996

$\mathbf{0 . 0 1 5} 0.004$

$\mathbf{0 . 0 9 2} \quad 0.004$

$\mathbf{0 . 0 4 6} 0.005$

$\mathbf{0 . 0 8 2} \quad 0.006$

$\mathbf{0 . 0 6 1} 0.004$

$\mathbf{0 . 0 9 0} \quad 0.005$

$\mathbf{0 . 0 6 1} 0.004$

$\mathbf{0 . 0 6 9} \quad 0.005$

$\mathbf{0 . 0 5 8} \quad 0.005$

$\mathbf{0 . 0 7 1} 0.006$

$\mathbf{0 . 0 9 2} \quad 0.005$

$\mathbf{0 . 0 3 8} 0.003$

time dummy for January of 1997

time dummy for February of 1997

$\mathbf{0 . 0 4 6} \quad 0.004$

$\mathbf{0 . 0 6 5} 0.004$

$\mathbf{0 . 0 7 7} \quad 0.005$

time dummy for April of 1997

time dummy for May of 1997

time dummy for June of 1997

time dummy for July of 1997

time dummy for August of 1997

time dummy for September of 1997

time dummy for October of 1997

time dummy for November of 1997

time dummy for December of 1997

time dummy for January of 1998

time dummy for February of 1998

$\mathbf{0 . 0 4 2} 0.005$

$\mathbf{0 . 0 5 4} \quad 0.004$

$\mathbf{0 . 0 7 7} 0.005$

$\mathbf{0 . 0 6 1} \quad 0.004$

$\mathbf{0 . 0 6 6} \quad 0.006$

$\mathbf{0 . 0 6 5} \quad 0.005$

$\mathbf{0 . 0 9 5} \quad 0.005$

$\mathbf{0 . 0 8 6} 0.006$

$\mathbf{0 . 0 3 1} 0.005$

$\mathbf{0 . 0 2 1} 0.004$

$\mathbf{0 . 1 2 2} 0.003$

$\mathbf{0 . 0 0 8} 0.005$

$\mathbf{0 . 0 7 2} 0.005$

$\mathbf{0 . 0 5 3} 0.005$

$\mathbf{0 . 0 5 8} \quad 0.004$

$\mathbf{0 . 0 6 8} 0.005$

$\mathbf{0 . 0 4 7} 0.005$

$\mathbf{0 . 0 4 2} 0.005$

$\mathbf{0 . 0 8 2} 0.005$

$\mathbf{0 . 0 5 2} 0.006$

$\mathbf{0 . 0 5 9} \quad 0.004$

$\mathbf{- 0 . 0 1 0} \quad 0.004$

$\mathbf{0 . 0 6 2} 0.003$

$\mathbf{0 . 0 4 0} \quad 0.005$

$\mathbf{0 . 0 7 3} 0.005$

$\mathbf{0 . 0 4 7} 0.004$

$\mathbf{0 . 0 5 5} 0.005$

$\mathbf{0 . 0 6 9} \quad 0.004$

$\mathbf{0 . 0 6 7} 0.005$

$\mathbf{0 . 0 6 5} \quad 0.004$

$\mathbf{0 . 0 4 1} 0.004$

$\mathbf{0 . 1 0 1} 0.006$

time dummy for December of 1999 
number of groups

(a) GLS estimates (coef), where the weights

are the square root of the inverse of the sample size.

Standard errors (se) are White-corrected and serial

correlation corrected across and within regions (assuming

an autoregressive process specific to each region).

(b) The dependent variable is average wages, which is one example of wage equation estimated in the paper.

The minimum wage variable is "fraction affected"

(c) Time effects are modeled with month dummies, region effects are modeled with region dummies, and labor supply

shifters are included as controls.

(d) To reflect a $10 \%$ increase in the minimum wage, the "fraction affected" estimate needs to be multiplied by 4.5 , which is the approximate elasticity of the minimum wage with respect to "fraction affected" 
Table C.2 - EMPLOYMENT EQUATION

\begin{tabular}{|c|c|c|}
\hline Independent Variables & coef & se \\
\hline fraction affected & 0.021 & 0.020 \\
\hline past inflation & -0.043 & 0.057 \\
\hline$\%$ young & -0.255 & 0.174 \\
\hline \% younger than 10 years old & -0.255 & 0.083 \\
\hline \% women & 0.046 & 0.138 \\
\hline$\%$ illiterate & -0.193 & 0.240 \\
\hline \% student & 0.506 & 0.142 \\
\hline \% retiree & 0.047 & 0.186 \\
\hline$\%$ in urban areas & 0.014 & 0.170 \\
\hline$\%$ working in the informal sector & 0.510 & 0.125 \\
\hline$\%$ working in the public sector (municipal and estate jobs) & -1.991 & 0.257 \\
\hline$\%$ working in the public sector (federal jobs) & -2.909 & 0.564 \\
\hline$\%$ workers in the building construction industry & 0.818 & 0.240 \\
\hline$\%$ workers in the metallurgic industry & 0.485 & 0.183 \\
\hline \% working on two jobs & -1.075 & 0.388 \\
\hline$\%$ with basic ( 8 years of) education & -0.070 & 0.155 \\
\hline$\%$ with high (11 years of) education & -0.141 & 0.183 \\
\hline average years of education & -0.213 & 0.238 \\
\hline regional dummy for Pernambuco & 0.000 & 0.002 \\
\hline regional dummy for Minas Gerais & 0.000 & 0.002 \\
\hline regional dummy for Rio de Janeiro & 0.001 & 0.002 \\
\hline regional dummy for Sao Paulo & 0.000 & 0.002 \\
\hline regional dummy for Rio Grande do Sul & 0.000 & 0.002 \\
\hline constant & 0.023 & 0.004 \\
\hline 1st lag of total employment & -0.459 & 0.035 \\
\hline 2nd lag of total employment & -0.319 & 0.038 \\
\hline 3rd lag of total employment & -0.240 & 0.040 \\
\hline 4th lag of total employment & -0.232 & 0.042 \\
\hline 5th lag of total employment & -0.286 & 0.043 \\
\hline 6th lag of total employment & -0.234 & 0.045 \\
\hline 7th lag of total employment & -0.216 & 0.046 \\
\hline 8th lag of total employment & -0.185 & 0.047 \\
\hline 9th lag of total employment & -0.162 & 0.047 \\
\hline 10th lag of total employment & -0.119 & 0.048 \\
\hline 11th lag of total employment & -0.121 & 0.049 \\
\hline 12th lag of total employment & 0.125 & 0.049 \\
\hline 13th lag of total employment & 0.039 & 0.049 \\
\hline 14th lag of total employment & 0.014 & 0.049 \\
\hline 15th lag of total employment & -0.037 & 0.048 \\
\hline 16th lag of total employment & -0.039 & 0.047 \\
\hline 17th lag of total employment & -0.047 & 0.046 \\
\hline 18th lag of total employment & -0.045 & 0.045 \\
\hline 19th lag of total employment & -0.005 & 0.044 \\
\hline 20th lag of total employment & -0.025 & 0.043 \\
\hline 21st lag of total employment & -0.062 & 0.041 \\
\hline 22nd lag of total employment & -0.040 & 0.040 \\
\hline 23rd lag of total employment & 0.059 & 0.038 \\
\hline 24th lag of total employment & 0.095 & 0.035 \\
\hline time dummy for June of 1986 & -0.022 & 0.006 \\
\hline time dummy for July of 1986 & 0.001 & 0.006 \\
\hline time dummy for August of 1986 & 0.002 & 0.005 \\
\hline time dummy for September of 1986 & -0.006 & 0.006 \\
\hline time dummy for October of 1986 & 0.000 & 0.006 \\
\hline time dummy for November of 1986 & -0.048 & 0.006 \\
\hline time dummy for December of 1986 & 0.002 & 0.006 \\
\hline time dummy for January of 1987 & -0.001 & 0.006 \\
\hline time dummy for February of 1987 & -0.061 & 0.009 \\
\hline time dummy for March of 1987 & -0.028 & 0.010 \\
\hline time dummy for April of 1987 & -0.013 & 0.010 \\
\hline time dummy for May of 1987 & -0.017 & 0.011 \\
\hline time dummy for June of 1987 & -0.017 & 0.013 \\
\hline time dummy for July of 1987 & -0.012 & 0.013 \\
\hline time dummy for August of 1987 & -0.027 & 0.010 \\
\hline time dummy for September of 1987 & -0.031 & 0.007 \\
\hline time dummy for October of 1987 & -0.021 & 0.006 \\
\hline time dummy for November of 1987 & -0.035 & 0.007 \\
\hline time dummy for December of 1987 & -0.019 & 0.009 \\
\hline time dummy for January of 1988 & -0.070 & 0.010 \\
\hline time dummy for February of 1988 & 0.010 & 0.010 \\
\hline
\end{tabular}


time dummy for May of 1988

time dummy for December of 1988

time dummy for March of 1989

time dummy for April of 1989

time dummy for May of 1989

time dummy for June of 1989

time dummy for July of 1989

time dummy for August of 1989

time dummy for September of 1989

time dummy for October of 1989

time dummy for November of 1989

$\mathbf{- 0 . 0 1 4} \quad 0.008$

$\mathbf{- 0 . 0 1 0} \quad 0.007$

$\mathbf{- 0 . 0 2 7} \quad 0.009$

$\mathbf{0 . 0 0 2} 0.014$

$\mathbf{- 0 . 0 1 6} \quad 0.017$

$\mathbf{0 . 0 0 4} 0.017$

$\mathbf{0 . 0 0 7} 0.021$

$\mathbf{- 0 . 0 2 4} \quad 0.022$

time dummy for December of 1989

$-0.026 \quad 0.025$

time dummy for January of 1990

time dummy for February of 1990

$\mathbf{- 0 . 0 1 7} \quad 0.028$

time dummy for March of 1990

time dummy for April of 1990

0.038

0.034

$\mathbf{0 . 0 3 1} \quad 0.041$

time dummy for May of 1990

time dummy for June of 1990

time dummy for July of 1990

time dummy for August of 1990

time dummy for September of 1990

time dummy for October of 1990

time dummy for November of 1990

$\mathbf{0 . 0 1 5} \quad 0.045$

$\mathbf{- 0 . 0 2 2} \quad 0.026$

$\mathbf{- 0 . 0 2 1} 0.008$

$\mathbf{- 0 . 0 1 0} \quad 0.008$

$\mathbf{- 0 . 0 2 5} \quad 0.008$

$\mathbf{- 0 . 0 4 7} \quad 0.008$

$\mathbf{- 0 . 0 0 9} \quad 0.009$

$\mathbf{- 0 . 0 5 1} \quad 0.010$

time dummy for December of 1990

time dummy for January of 1991

time dummy for February of 1991

$-\mathbf{0 . 0 6 2} \quad 0.010$

$\mathbf{- 0 . 0 3 9} \quad 0.012$

time dummy for March of 1991

$\begin{array}{ll}\mathbf{0 . 0 0 6} & 0.013 \\ \mathbf{0 . 0 2 5} & 0.013\end{array}$

time dummy for April of 1991

$\mathbf{- 0 . 0 2 4} \quad 0.010$

time dummy for May of 1991

time dummy for June of 1991

time dummy for July of 1991

time dummy for August of 1991

time dummy for September of 1991

time dummy for October of 1991

time dummy for November of 1991

time dummy for December of 1991

time dummy for January of 1992

time dummy for February of 1992

$\mathbf{- 0 . 0 0 3} \quad 0.007$

$\mathbf{- 0 . 0 0 8} \quad 0.007$

$\mathbf{- 0 . 0 0 9} \quad 0.008$

$\mathbf{- 0 . 0 1 1} \quad 0.008$

$\mathbf{- 0 . 0 1 0} \quad 0.011$

$\mathbf{- 0 . 0 2 0} \quad 0.011$

$\mathbf{- 0 . 0 3 3} \quad 0.011$

$\mathbf{- 0 . 0 2 0} \quad 0.014$

$\mathbf{- 0 . 0 0 1} \quad 0.015$

$\mathbf{- 0 . 0 5 7} \quad 0.015$

$\mathbf{- 0 . 0 5 7} \quad 0.015$

time dummy for March of 1992

time dummy for April of 1992

time dummy for May of 1992

time dummy for June of 1992

time dummy for July of 1992

time dummy for August of 1992

time dummy for September of 1992

time dummy for October of 1992

time dummy for November of 1992

$\mathbf{0 . 0 1 7} 0.014$

$\mathbf{- 0 . 0 0 7} \quad 0.014$

$\mathbf{- 0 . 0 0 5} \quad 0.014$

$\mathbf{- 0 . 0 2 2} \quad 0.014$

$\mathbf{- 0 . 0 1 5} \quad 0.013$

$\mathbf{- 0 . 0 3 1} \quad 0.014$

$\mathbf{- 0 . 0 0 4} \quad 0.014$

$\mathbf{0 . 0 0 3} \quad 0.015$

$\mathbf{- 0 . 0 0 8} \quad 0.015$

time dummy for December of 1992

time dummy for January of 1993

time dummy for February of 1993

$\mathbf{- 0 . 0 6 5} \quad 0.016$

$\mathbf{0 . 0 3 6} \quad 0.016$

time dummy for March of 1993

$\mathbf{- 0 . 0 4 7} \quad 0.016$

time dummy for April of 1993

$\mathbf{0 . 0 2 0} \quad 0.016$

time dummy for May of 1993

$\mathbf{- 0 . 0 1 3} 0.017$

$\mathbf{- 0 . 0 1 9} \quad 0.017$

ime dummy for June of 1993

time dummy for July of 1993

time dummy for August of 1993

time dummy for September of 1993

time dummy for October of 1993

time dummy for November of 1993

time dummy for December of 1993

time dummy for January of 1994

time dummy for February of 1994 
time dummy for March of 1994

time dummy for April of 1994

time dummy for May of 1994

time dummy for June of 1994

time dummy for July of 1994

0.015

time dummy for August of 1994

$\mathbf{0 . 0 0 8} \quad 0.023$

time dummy for September of 1994

$-0.022$

0.023

time dummy for October of 1994

$\mathbf{- 0 . 0 0 6} \quad 0.005$

time dummy for November of 1994

$\mathbf{- 0 . 0 0 1} \quad 0.005$

time dummy for December of 1994

$\mathbf{- 0 . 0 2 6} \quad 0.006$

time dummy for January of 1995

0.006

time dummy for February of 1995

$\mathbf{0 . 0 0 5} 0.003$

time dummy for March of 1995

$\mathbf{- 0 . 0 0 4} \quad 0.006$

time dummy for April of 1995

time dummy for May of 1995

time dummy for June of 1995

time dummy for July of 1995

time dummy for August of 1995

time dummy for September of 1995

time dummy for October of 1995

time dummy for November of 1995

$\mathbf{- 0 . 0 5 5} 0.005$

$\mathbf{- 0 . 0 1 5} \quad 0.006$

$\mathbf{- 0 . 0 2 1} 0.006$

$\mathbf{- 0 . 0 1 4} \quad 0.005$

$\mathbf{- 0 . 0 1 2} \quad 0.005$

$\mathbf{- 0 . 0 3 9} \quad 0.005$

$\mathbf{- 0 . 0 2 2} \quad 0.005$

$\mathbf{- 0 . 0 1 6} \quad 0.005$

$\mathbf{- 0 . 0 3 7} \quad 0.005$

$\mathbf{- 0 . 0 3 6} \quad 0.005$

time dummy for January of 1996

time dummy for February of 1996

$\begin{array}{rr}\mathbf{- 0 . 0 6 6} & 0.005 \\ \mathbf{0 . 0 0 1} & 0.006\end{array}$

$\mathbf{- 0 . 0 2 5} \quad 0.005$

time dummy for March of 1996

time dummy for April of 1996

time dummy for May of 1996

time dummy for June of 1996

time dummy for July of 1996

time dummy for August of 1996

time dummy for September of 1996

time dummy for October of 1996

time dummy for November of 1996

$\mathbf{- 0 . 0 0 8} \quad 0.004$

$\mathbf{- 0 . 0 3 3} \quad 0.005$

$\mathbf{- 0 . 0 2 6} \quad 0.005$

$\mathbf{- 0 . 0 1 5} \quad 0.005$

$\mathbf{- 0 . 0 1 5} \quad 0.004$

$\mathbf{- 0 . 0 2 7} \quad 0.005$

$\mathbf{- 0 . 0 1 3} \quad 0.005$

$\mathbf{- 0 . 0 3 5} \quad 0.005$

$\mathbf{- 0 . 0 2 5} \quad 0.005$

$\mathbf{- 0 . 0 4 5} \quad 0.003$

time dummy for January of 1997

$\mathbf{- 0 . 0 2 0} \quad 0.005$

time dummy for February of 1997

0.005

$\begin{array}{ll}\mathbf{- 0 . 0 0 3} & 0.005 \\ -\mathbf{0 . 0 3 3} & 0.005\end{array}$

time dummy for April of 1997

time dummy for May of 1997

time dummy for June of 1997

time dummy for July of 1997

time dummy for August of 1997

time dummy for September of 1997

time dummy for October of 1997

time dummy for November of 1997

time dummy for December of 1997

$\begin{array}{ll}-\mathbf{0 . 0 1 5} & 0.005\end{array}$

$\mathbf{- 0 . 0 3 4} \quad 0.005$

$\mathbf{- 0 . 0 1 3} 0.005$

$\mathbf{- 0 . 0 1 6} \quad 0.005$

$\mathbf{- 0 . 0 1 8} \quad 0.005$

$\mathbf{- 0 . 0 1 7} \quad 0.005$

$\mathbf{- 0 . 0 5 3} \quad 0.004$

$\mathbf{- 0 . 0 4 3} \quad 0.005$

$\mathbf{- 0 . 0 6 3} \quad 0.004$

-0.009 0.005

time dummy for February of 1998

time dummy for March of 1998

time dummy for April of 1998

time dummy for May of 1998

time dummy for June of 1998

time dummy for July of 1998

time dummy for August of 1998

time dummy for September of 1998

time dummy for October of 1998

time dummy for November of 1998

$\begin{array}{ll}\mathbf{- 0 . 0 7 2} & 0.005 \\ \mathbf{- 0 . 0 0 1} & 0.005\end{array}$

$\mathbf{- 0 . 0 4 1} \quad 0.006$

$\mathbf{- 0 . 0 3 2} 0.005$

$\mathbf{- 0 . 0 1 4} \quad 0.005$

$\mathbf{- 0 . 0 3 2} 0.005$

$\mathbf{- 0 . 0 3 6} \quad 0.005$

$\mathbf{- 0 . 0 2 8} \quad 0.006$

$\mathbf{- 0 . 0 3 1} \quad 0.005$

$\mathbf{- 0 . 0 3 6} \quad 0.005$

time dummy for December of 1998

time dummy for January of 1999

$\mathbf{- 0 . 0 6 7} \quad 0.004$

time dummy for February of 1999

$\mathbf{0 . 0 0 9} \quad 0.005$

time dummy for March of 1999

$\mathbf{- 0 . 0 1 4} \quad 0.005$

time dummy for April of 1999

$-0.007$

0.005

$\mathbf{- 0 . 0 3 1} 0.005$

time dummy for June of 1999

$-0.027$

0.005

time dummy for July of 1999

$-0.018$

0.006

time dummy for August of 1999

time dummy for September of 1999

time dummy for October of 1999

$-\mathbf{0 . 0 3 1} \quad 0.005$

$\begin{array}{ll}\mathbf{- 0 . 0 2 4} & 0.005\end{array}$

time dummy for November of 1999

$\mathbf{- 0 . 0 2 1} \quad 0.006$

$\mathbf{0 . 0 1 4} \quad 0.005$

time dummy tor December of $199 y$ 
number of groups

(a) GLS estimates (coef), where the weight are the square root of the inverse of the sample size.

Standard errors (se) are White-corrected and serial correlation corrected across and within regions (assuming

an autoregressive process specific to each region).

(b) The dependent variable is average hours worked for the labour force, which is one example of the employment equation estimated in the paper. The model is in differences The minimum wage variable is "fraction affected"

(c) Time effects are modeled with month dummies, region effects are modelled with region dummies, and labour supply shifters are included as controls.

(d) To reflect a $10 \%$ increase in the minimum wage, the "fraction affected" estimate needs to be multiplied by 4.5 , which is the approximate elasticity of the minimum wage with respect to "fraction affected" 